BNWL-20

AEC

RESEARCH and

DEVELOPMENT REPORT

\title{
THE DENSITY-FLOW RECIME OF FRANKLIN D. ROOSEVELT LAKE
}

MARCH 15, 1965
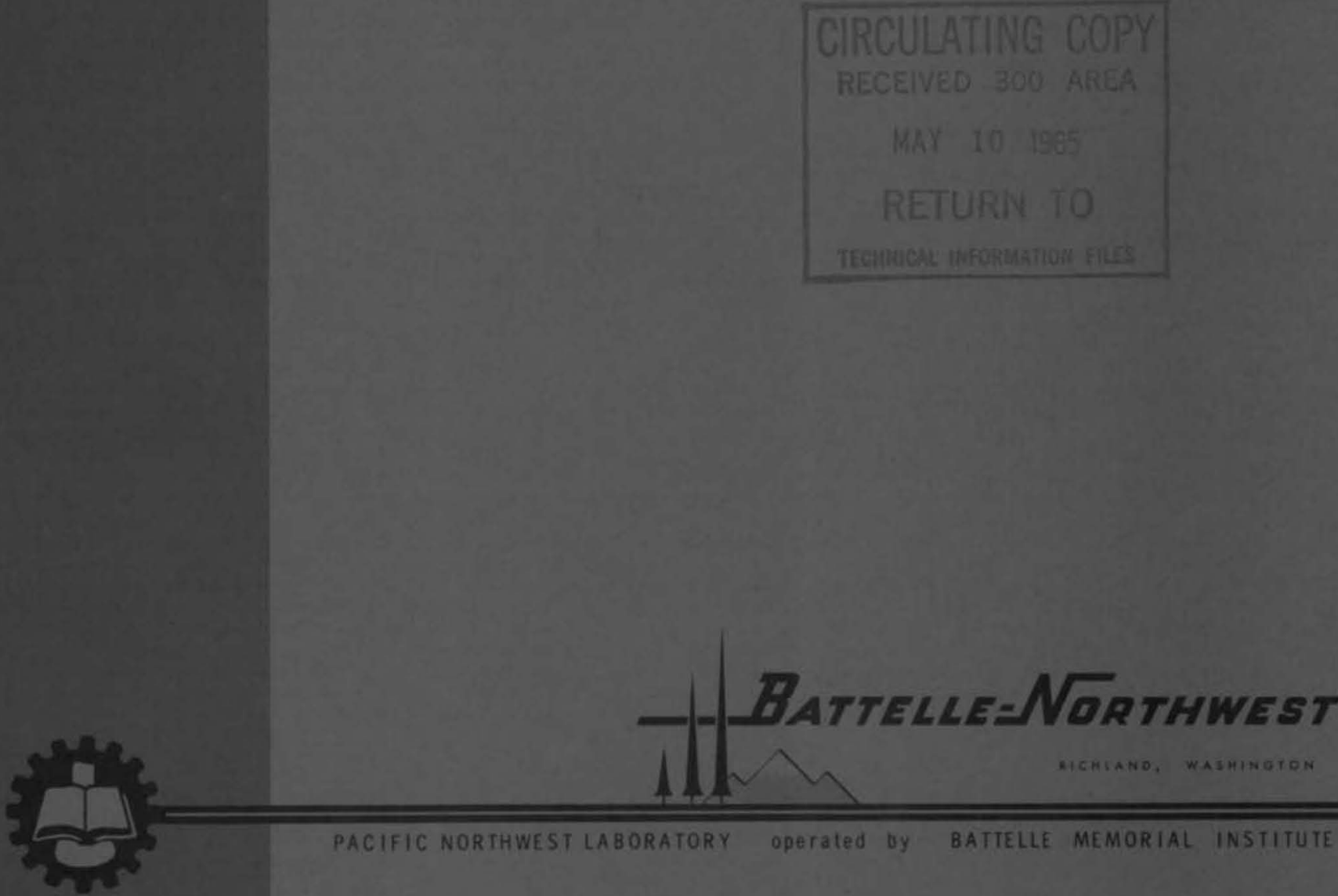


\section{LEGAL NOTICE}

This report was prepared as an account of Government sponsored work. Neither the United States, nor the Commission, nor any person acting on behalf of the Commissioni

A. Makes any warranty or representation, expressed or implied, with respect to the accuracy, completeness, or usefulness of the information contained in this report, or that the use of any information, apporatus, method, or process disclosed in this report may not infringe privately owned rights; or

B. Assumes any liabilities with respect to the use of, or for damages resulting from the use of any information, apparatus, method, or process disclosed in this report.

As used in the above, "person octing on behalf of the Commission" includes any employee or contractor of the Commission, or employee of such contractor, to the extent that such employee or contractor of the Commission, or employee of such contractor prepares, disseminotes, or provides access to, any information pursuant to his employment or contract with the Commission, or his employment with such contractor.

\section{PACIFIC NORTHWEST LABORATORY}

RICHLAND, WASHINGTON

Operated By

BATTELLE MEMORIAL. INSTITUTE

For the

U. 5. ATOMIC ENERGY COMMISSION Under Contract No. AT(45-1)-1830 


\author{
BNWL- 20 \\ UC-2, General, Miscellaneous, \\ and Progress Reports \\ (TID-4500. 39th Ed.)
}

THE DENSITY - FLOW REGIME

OF FRANKLIN D. ROOSEVELT LAKE*

By

R. T. Jaske

Technical Planning Section

Test Reactor and Engineering Services Department

March 15, 1965

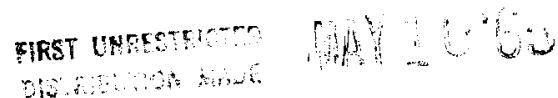

BATTELLE-NORTHWEST

PACIFIC NORTHWEST LABORATORY

OPERATED BY

BATTELLE MEMORIAL INSTITUTE

RICHLAND, WASHINGTON

Work performed under Contract No. AT(45-1)-1350 between the Atomic Energy Commission and the General Electric Company, and Contract No. AT(45-1)- 1830 between the Atomic Energy Commission and Battelle Memorial Institute.

Printed by/for the U.S. Atomic Energy Commission

*This work is based on previously unpublished data furnished by the Bureau of Commercial Fisheries, Fish Attraction Research Program. 


\begin{abstract}
A correlation of $2 \mathrm{yr}$ data describing the thermal regime of Lake Roosevelt and comparisons with Yih's theoretical work and Debler's laboratory studies shows excellent agreement regarding the position of the interfacial layer between the upper relatively stagnant zone and the region of the primary flow transport. This agreement, however, could easily lead the investigator to conclusions regarding the entire flow regime that cannot be supported.

Further study of the temperature data and confirmation by velometer shows the location of a second, lower interface that roughly conforms to the one above but showing "waves" of instability. It is apparent that more complex theory will have to account for the variance between dynamic and static equilibrium.

The study indicates that information on refined mass transport relations is necessary for heat budget studies. The study also indicates that projects or operational concepts involving storage or release of cool water are made difficult because density currents tend to bypass cooler masses. The dynamic equilibrium prevents the formation of "normal" density currents and, as a result, Lake Roosevelt fills with cool water by displacement from the North without any significant horizontal distribution.
\end{abstract}


THE DENSITY - FLOW REGIME

OF FRANKLIN D. ROOSEVELT LAKE

\section{INTRODUCTION}

During 1964, a detailed study of the temperature and density of Lake Roosevelt was undertaken. This study was performed at the request of several agencies; there had long been a need for a better understanding of the Lake's thermal movements. Recently, there had been problems in accounting for cool water masses experienced during Hanford's annual river cooling program.

Considerable emphasis has been placed on the thermal regime of Lake Roosevelt as it contributes to the overall picture expected after completion of the U. S. - Canadian Treaty Projects. Reservoirs are known to distort both the extent and timing of the natural, annual thermal cycle. Recognizing that such structures were planned and constructed before serious study of thermal effects was integrated with project planning, some agencies now seek not only to improve the understanding of these effects but to capitalize on the advantages where practicable. In regard to this report, the programs of the Bureau of Commercial Fisheries and the U. S. Atomic Energy Commission fall in this category.

\section{EXPERIMENTAL PROCEDURE}

Because of the distances involved, and the desire to minimize data bias because of time, aircraft was chosen for all data surveys. The lake was divided into ten segments of 10 miles in length, which appeared to give appropriate coverage on the basis of previous experience. Consideration was then given to the thermal measurements.

In previous years, thermocouples read with a standard decade box and ice bath were used. This cumbersome array was supplanted in 1963 by a Wallac Resistance Temperature Detector having case compensation and a 110 meter probe. Data obtained with this instrument were precise to \pm 0.1 C. Previous experience had shown the necessity to read data this 
closely to find thermal evidence of shear gradients with some confidence. Despite its accuracy, the Wallac instrument proved difficult to use because of cord weight and the length of time required to achieve equilibrium at each depth. A review of available equipment produced the following apparatus tailored for accuracy and aircraft transport.

These were the components:

- Power converter

A standard A. T. R. dc-ac inverter (Type 12T, Model RME, 12VDC input, $110 \mathrm{VAC}$ output, 60 cycle, 90 watt continuous power) that used the Cessna 180 power supply to run the chart recorder.

- Temperature measurement system

The temperature measurement system was a portable, battery regulated, three resistance bridge unit (Rosemount Eng. Model 410B). A switch provided a selection of three temperature ranges (0 to $10 \mathrm{C}$, 10 to $20 \mathrm{C}, 20$ to $30 \mathrm{C}$. All resistance bridges were factory calibrated for the sensor and cable and were factory installed. The bridge residual effect ranges from 0.002 to $0.05 \%$ of full scale output voltage (output voltage range is 0.00000 to 0.010000 ).

- Thermister and cable

Included in the water temperature measuring system is a platinum resistance immersion sensor and $400 \mathrm{ft}$ of cable. Time constant of the sensor is 2.5 and the accuracy is $\pm 0.05 \mathrm{C}$. The four wire cable is marked with a color code and numbers to facilitate rapid depth identification of the sensor.

- Recorder

An Esterline Angus 6 in. recording Labograph with a servo potentiometer measuring measuring element was used to record the temperature. Response of this instrument is $1 / 8$ full scale, accuracy $0.5 \%$ of full scale and sensitivity $1 / 8 \%$ full scale. Depth was recorded on the chart at each $0.2 \mathrm{C}$ temperature change throughout the depth of the profile. 
Commencing April 15, 1964, flights were made weekly, monitoring the ten stations. At each letdown, the equipment was checked against a certified thermometer and recording began until the probe bottom was manually indicated. A complete data run took less than $5 \mathrm{hr}$. The entire operation, based at Seattle, Washington, took less than $10 \mathrm{hr}$ per trip. Some weather interference was encountered and wind caused drift errors on some days; however, the entire operation was quite adequate and exceeded expectation. The recording equipment performed satisfactorily and no runs were aborted for this reason. The aircraft and experimental apparatus are illustrated in Figures 1 and 2.

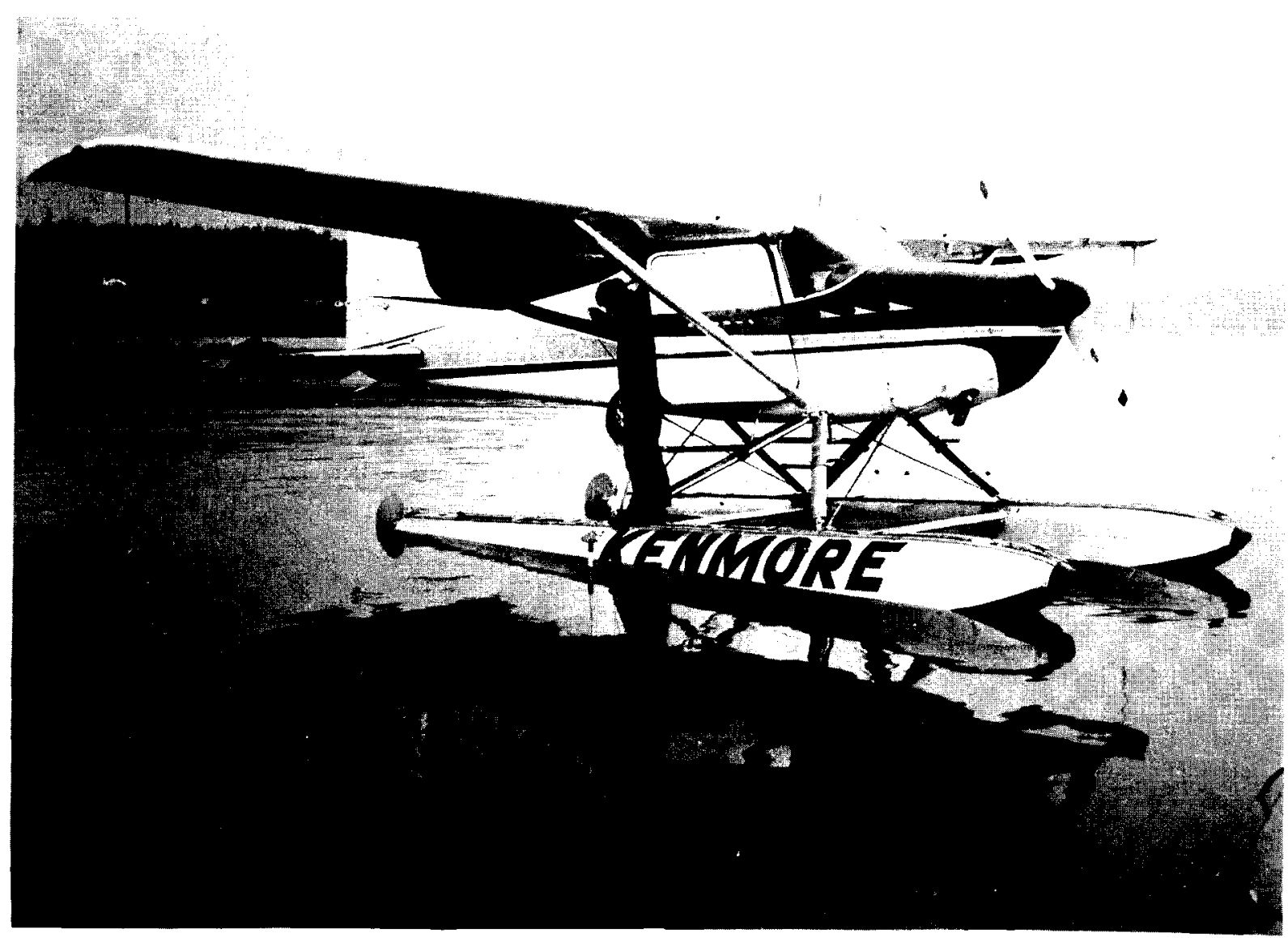

FIGURE 1

Cessna 180 Float Plane Used as Data Collection Platform 


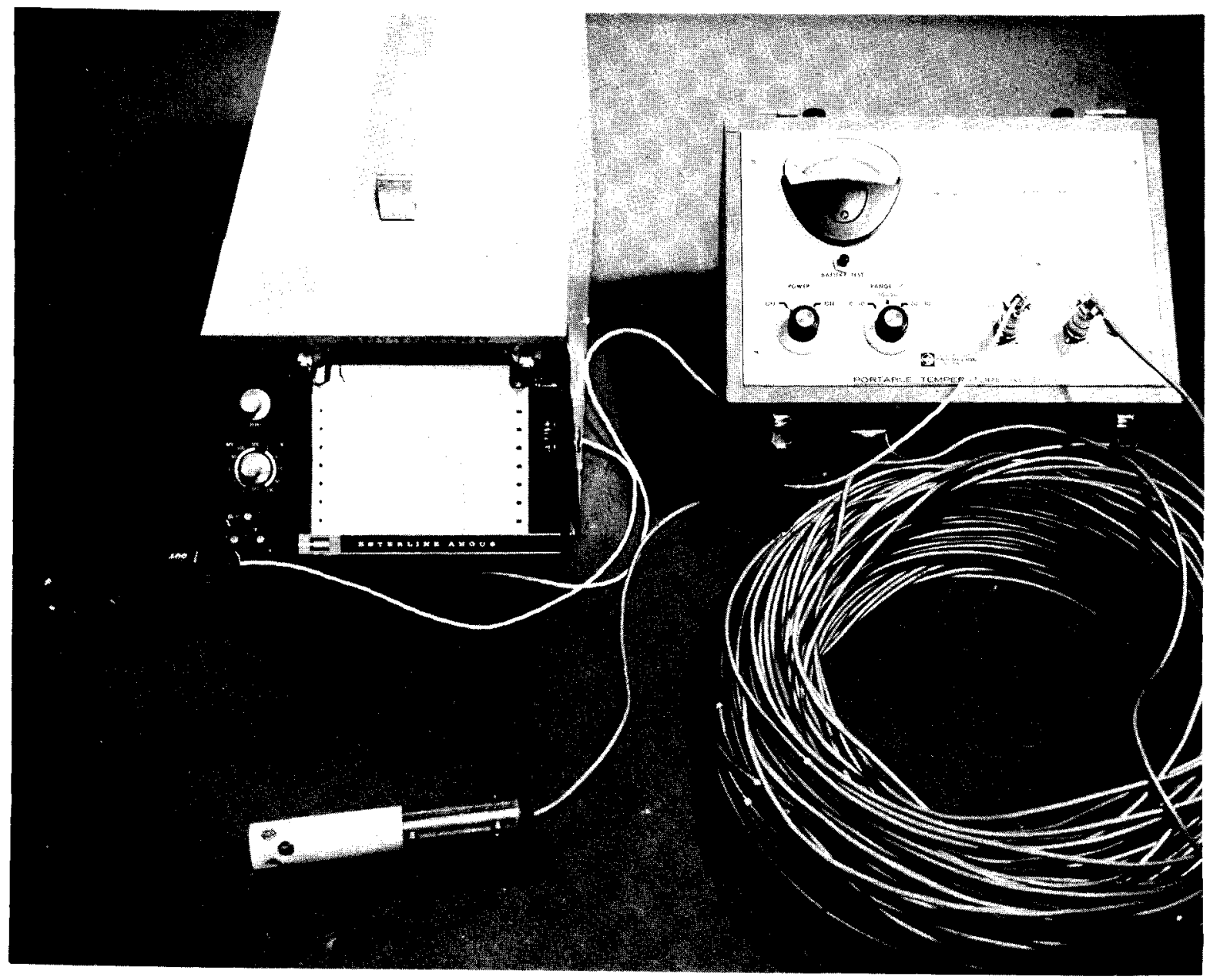

\section{FIGURE 2}

Apparatus on Bench

\section{DISCUSSION}

For several years, interest has centered on the development of improved heat budgets and better modeling of the density current behavior in reservoirs. The alteration of the normal temperature distribution has been described by Churchill ${ }^{(1)}$ and J. C. Ward ${ }^{(2)}$. Commencing in the early 1950's, these and other investigators began a search for an appropriate model of density current regime. In 1958, $\mathrm{Yih}^{(3)}$ reported that for large densimetric Froude numbers there was no tendency for flow separation. As the Froude number decreases below a critical value of $1 / \pi$, the conditions of the analysis predict that the entire depth of fluid 
cannot be in motion toward the outlet and an internal current with a thickness less than the total depth results.

In 1959, using laboratory troughs, Debler developed a correlation for the Yih prediction that the dividing streamline in a stratified reservoir could be modeled as a function of the densimetric Froude number, $F_{i}$ Figure 3 illustrates this relationship and is produced from Debler's original paper in the ASCE Journal. (4) The reader is encouraged to review the original reference for development of the mathematical analysis.

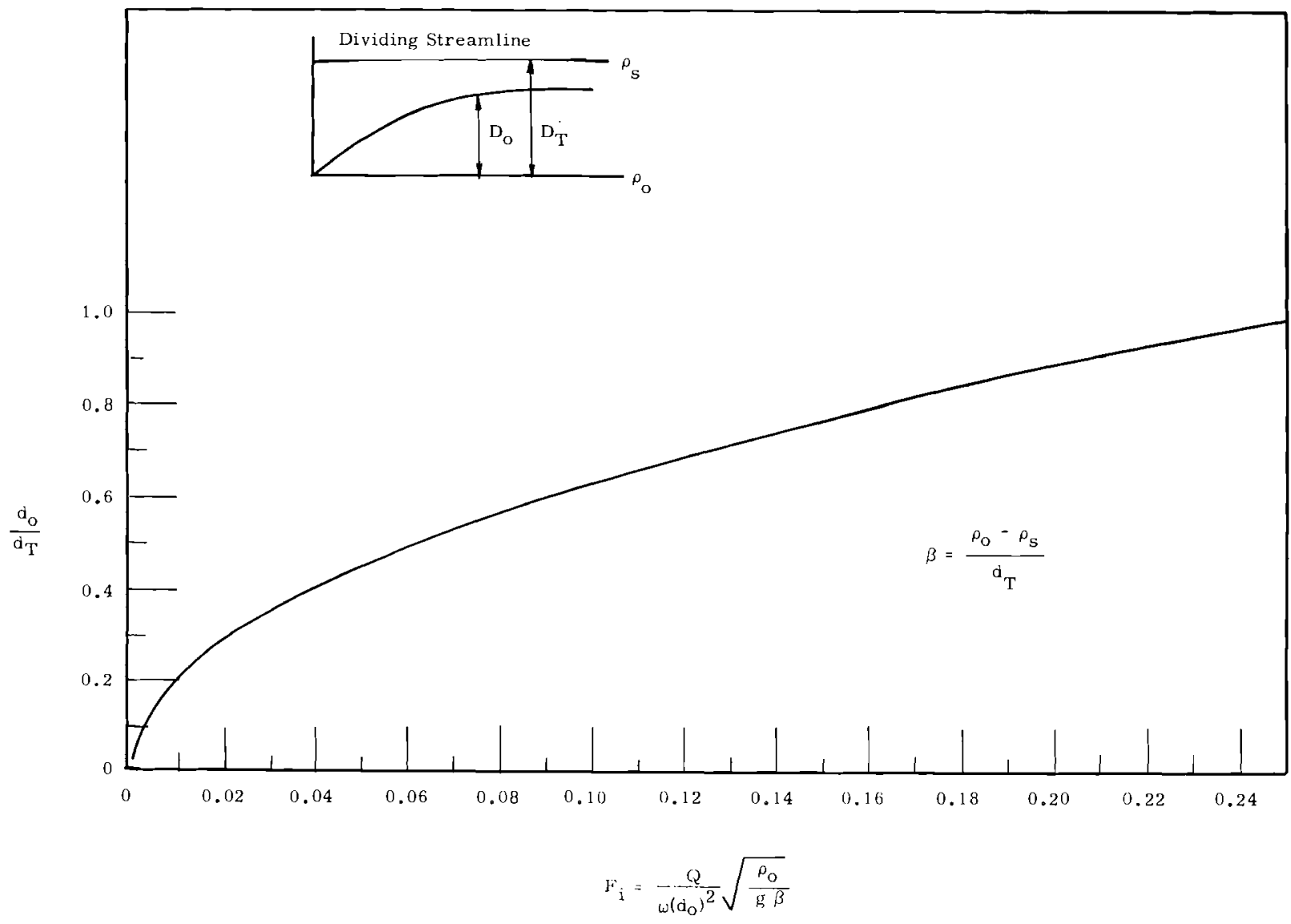

FIGURE 3

The Ratio of the Thickness of a Density Current to the Depth of Channel-Debler-1959

A study of this work reveals that three rather unnatural conditions were adopted to simplify the laboratory work.

- The tests were commenced from a state of static equilibrium at Reynolds number essentially zero 
- The flow outlet was located at the very bottom of the test trough

- The trough dimensions were chosen to minimize edge effects

While these conditions have application to a number of reservoirs, a study of many western reservoirs indicates that one or more of them does not exist. In Lake Roosevelt, none of the conditions exist.

Harleman, et al. ${ }^{(5)}$ have reported on application of this method to Fontana Reservoir in support of other project activity. While good correlation of the density current boundary was obtained, complications were encountered in explaining the action of the lower boundary since this dam had an outlet some distance above the bottom.

During this period, commencing in 1958, the Richland Operations Office of the U.S. Atomic Energy Commission through General Electric Company, then sole operating contractor at Hanford, arranged to alter the delivery of water from Grand Coulee Dam to favor a cooler water regime both above and below the river affected by the plant. Efforts to account for the cool water inventory were never fully successful. As additional dams were completed, the flow regime was further confused. However, the original incentives still remain of interest to both the $\mathrm{AEC}$ and the Fish and Wildlife Service. The necessity to account for heat balance in the special releases and the inability to do so using existing theory lent special emphasis to improved understanding of density currents in Lake Roosevelt.

Work is continuing. A promising, dynamic river model programmed for the IBM 7090 computer is currently being debugged at Hanford.

Accepted theory, developed on the concept of static equilibrium (Figure 4) would lead the investigator to conclude that density currents should develop and flow through Lake Roosevelt. The cooling program initiated by General Electric was operated on the assumption that the stratified upper layers could be trapped by reducing spill to zero, and discharging all cool water through the penstocks at the $1030 \mathrm{ft}$ elevation. 


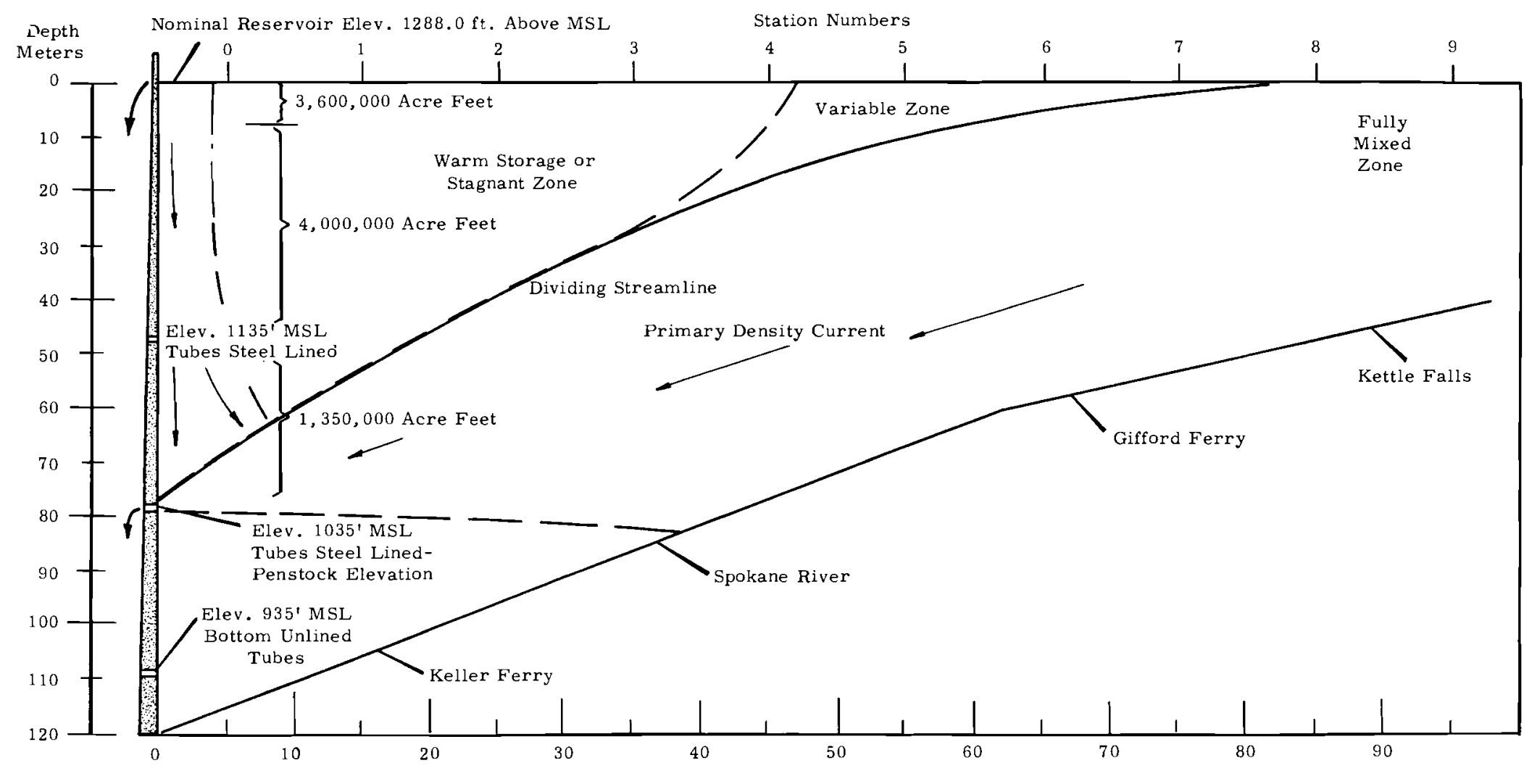

River Miles Above Grand Coulee Dam

\section{FIGURE 4}

Expected Density Currents and Other Reservoir Data 
Data collected in 1963, however, indicated that this expected density pattern was being interfered with by the dynamic flow conditions through the reservoir. The net effect was to cause dumping of warmer water while holding the cooler water. Replenishment of water from the North produced what appeared to be displacement flow rather than density flow. However, computation of the density interface using the Yih-Debler correlation indicated the presence of a dividing streamline. Clearly some additional influences were operating to alter the expected pattern.

As the 1964 data were compiled and density current boundaries computed, it became evident that the conditions of dynamic equilibrium were operating to create an additional sharply defined lower limit to the density flow regime. This lower limit appeared to cut through isotherms and further, rose and fell in response to the overall energy balance.

On September 3 and 4, 1964, a special set of data were taken at the 10 stations using both thermal detectors and velometers. The reservoir map, Figure 5, illustrates the unusual but not wholly unexpected result.

In Figure 5, the density current boundaries are located by velometer and defined as that portion of the stream having a velocity above the mean for any cross section. The original data and the derived boundaries are shown in Appendix 2. Appendix 3 shows a plot of the correlation between thermal gradients and observed shear zones and illustrates the technique used in defining "observed boundaries" using temperature traverse data. Velometer measurements were used only for the September 2-3 studies; the balance of the study is based on temperature depth recordings.

Further examination of the previous temperature data records confirmed the existence of both the upper and lower shear boundaries. The existence of a current band cutting through isotherms, but responding to static forces of stratification explained the tendency of the reservoir to drain like a dump truck using the drainage elevation of $1030 \mathrm{ft}$ as a fulcrum. 
Station Numbers

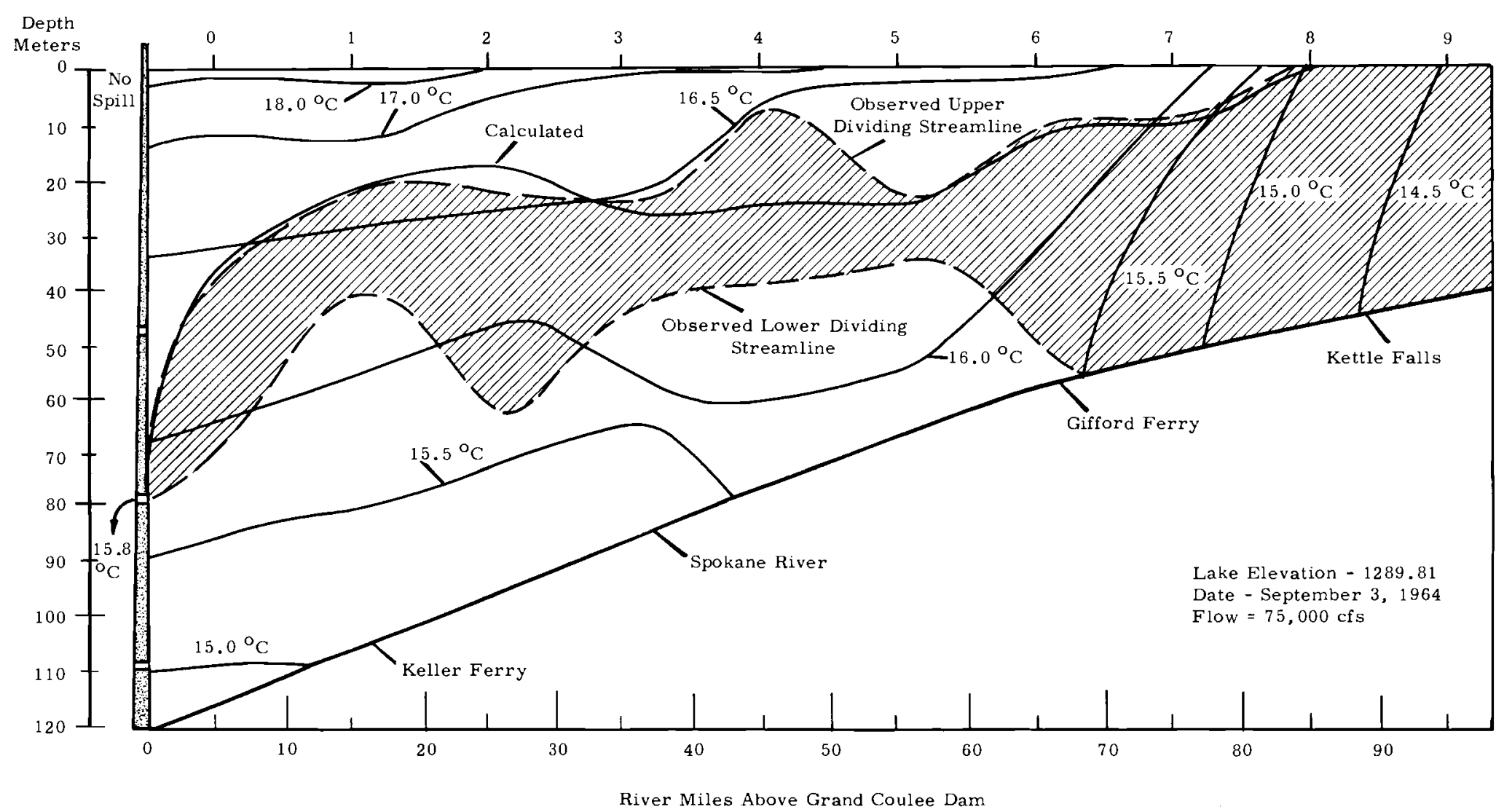

FIGURE 5

Lake Roosevelt Flow Regime and Principal Isotherms 
To illustrate the development of reservoir strata and the current path, Figures $6,7,8$, and 9 (see pp. 14 through 25) are included showing a consecutive $12 \mathrm{wk}$ period from July 27, 1964, until October 12, 1964. These illustrations, with the computed and observed flow boundaries, show the anticipated effects.

Efforts to correlate the bottom interface as a function of both static and dynamic forces are still underway at Battelle-Northwest. It is expected that the additional related work will be completed in 1965, but we felt that this material would be of sufficient interest to warrant publication before all findings are in.

\section{CONCLUSIONS}

As a result of this program, it appears that the following conclusions are appropriate:

- The correlation of the upper boundary predicted by Yih and demonstrated by Debler in trough experiments is sufficiently correct to be applied generally to stratified reservoirs. This applies to rapidly flowing reservoirs as well as relatively quiet systems.

- The bottom of the flow path created in a reservoir by discharge from a point below the surface does not necessarily remain below the elevation of the point of discharge. Rather, because of the conditions imposed by dynamic forces, the flow path separation layer or shear zone follows dynamic influences similar to the upper boundary and rises as necessary to maintain dynamic equilibrium.

- In the regime studied, the term stagnant zone is purely relative. At no time were velocities less than $0.05 \mathrm{ft} / \mathrm{sec}$ measured at any elevation. Velocity distribution both above and below the flow path was essentially the same. Velocities in the flow path were from 3 to 4 times those in the so-called stagnant zones.

- Operational concepts which envision use of the storage capacity of Lake Roosevelt to alter thermal conditions either expected from 
storage upstream in Canadian Treaty Reservoirs or currently existing must be designed to cope with the actual flow regime discovered. It is quite apparent that the reservoir does fill by displacement from the North and does not develop a true density current regime of any significance. This does not preclude operational plans which would save cold water by curtailment of the annual spring draw-down for flood control if sufficient upstream storage volume can be found to supplant the volume currently drained each spring. Retention of this cold water now discharged for flood control would restore some of the seasonal imbalance in Columbia River temperatures currently existing.

- Downstream activities sensitive to dissolved ion and turbidity content are affected by reservoir flow path which bypasses cooler chemically rich Spokane River in flows. Temporary holdup of this in flow, bearing a large percentage of the dissolved material sensitive to activation by downstream nuclear processes, may account for the annual diminution of $\mathrm{P}^{32}$ content normally observed below the Hanford Plant.

\section{ACKNOWLEDGEMENT}

The author acknowledges the cooperation of Raymond Seely, Power Superintendent, and his staff at Grand Coule Dam, for their performance of special operations, reading temperature records, and operating facilities. Further, acknowledgement is given to G. R. Snyder and the United States Fish and Wildlife Service for the use of original data, photographs and 1964 surveys. The information is part of the program of the Fish Attraction Research Program of the Bureau of Commercial Fisheries located at Seattle, Washington, under direction of G. B. Collins. 


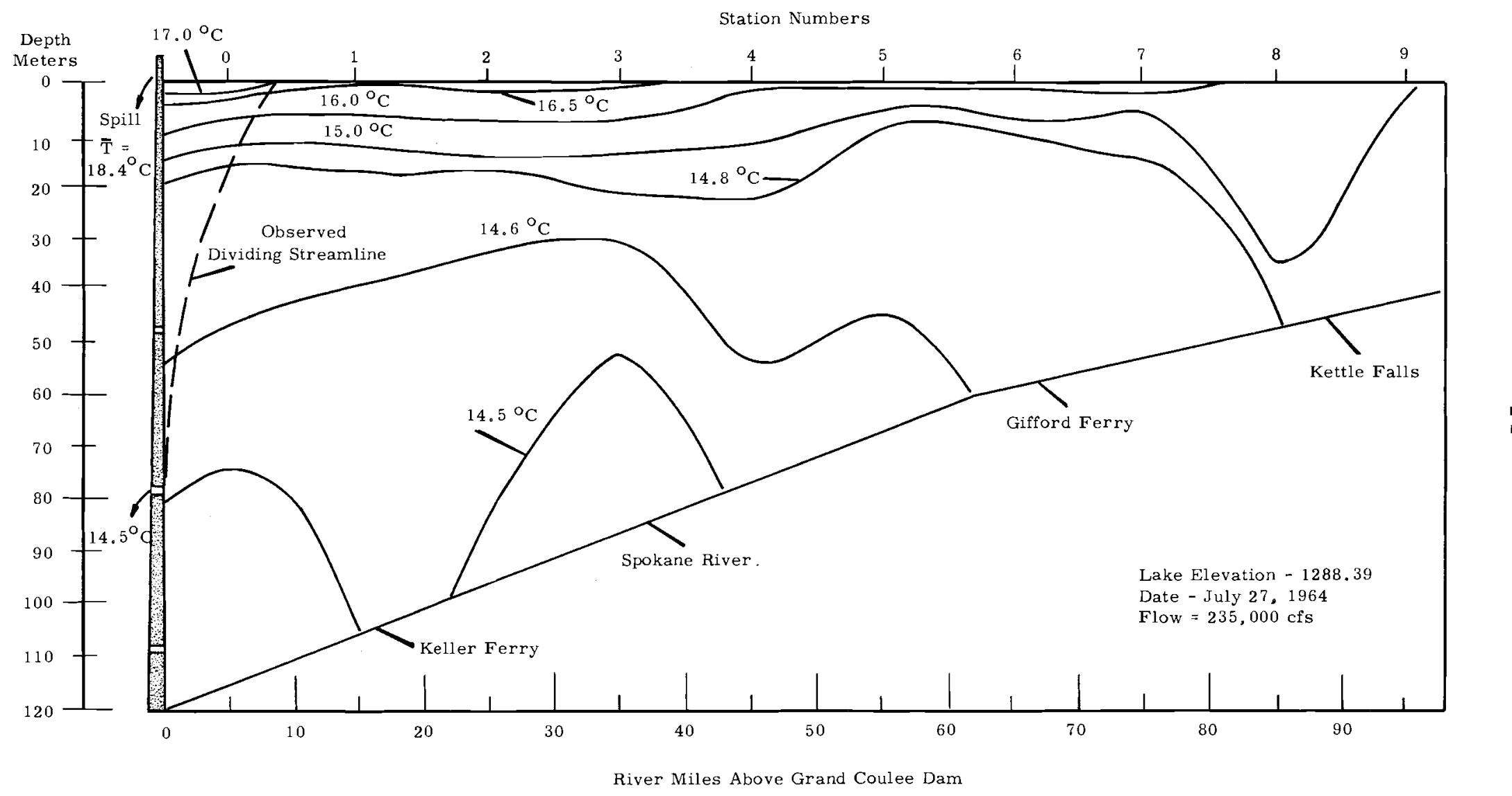

\section{FIGURE 6a}

Development of Density-Flow Regime - July 27, 1964 


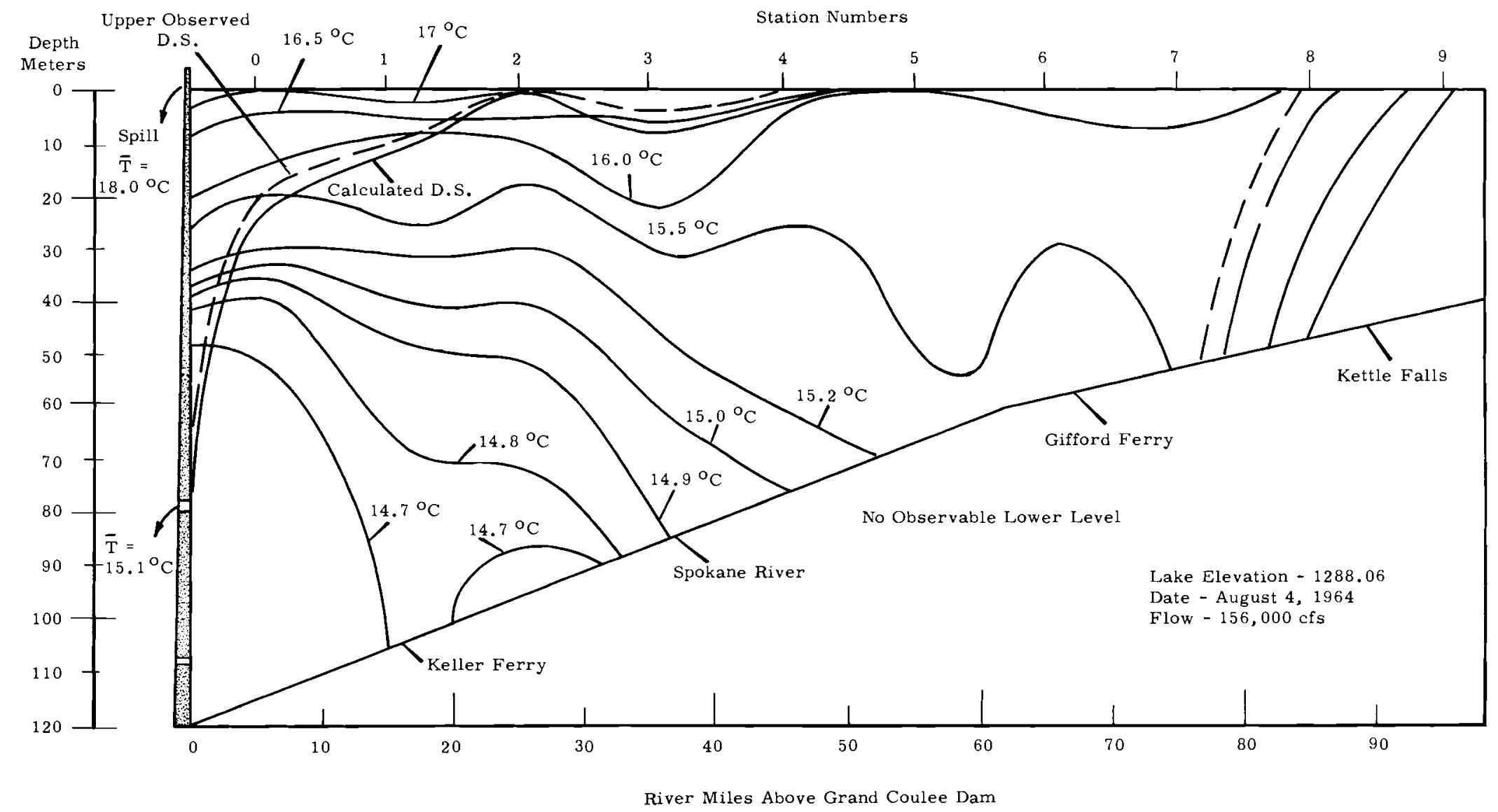

FIGURE 6b

Development of Density-Flow Regime - August 4, 1964 


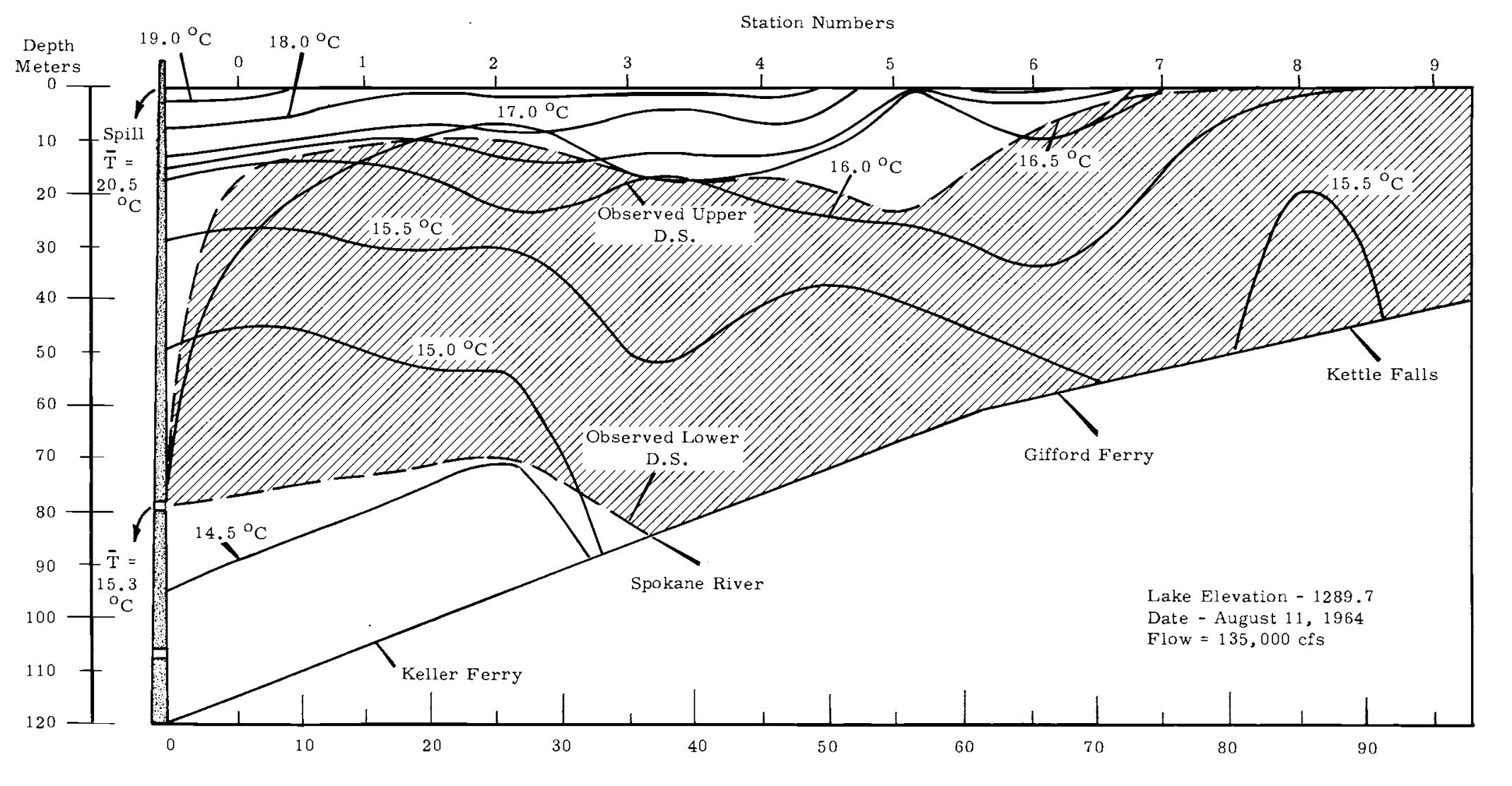

River Miles Above Grand Coulee Dam

\section{FIGURE 6c}

Development of Density-Flow Regime - August 11, 1964 


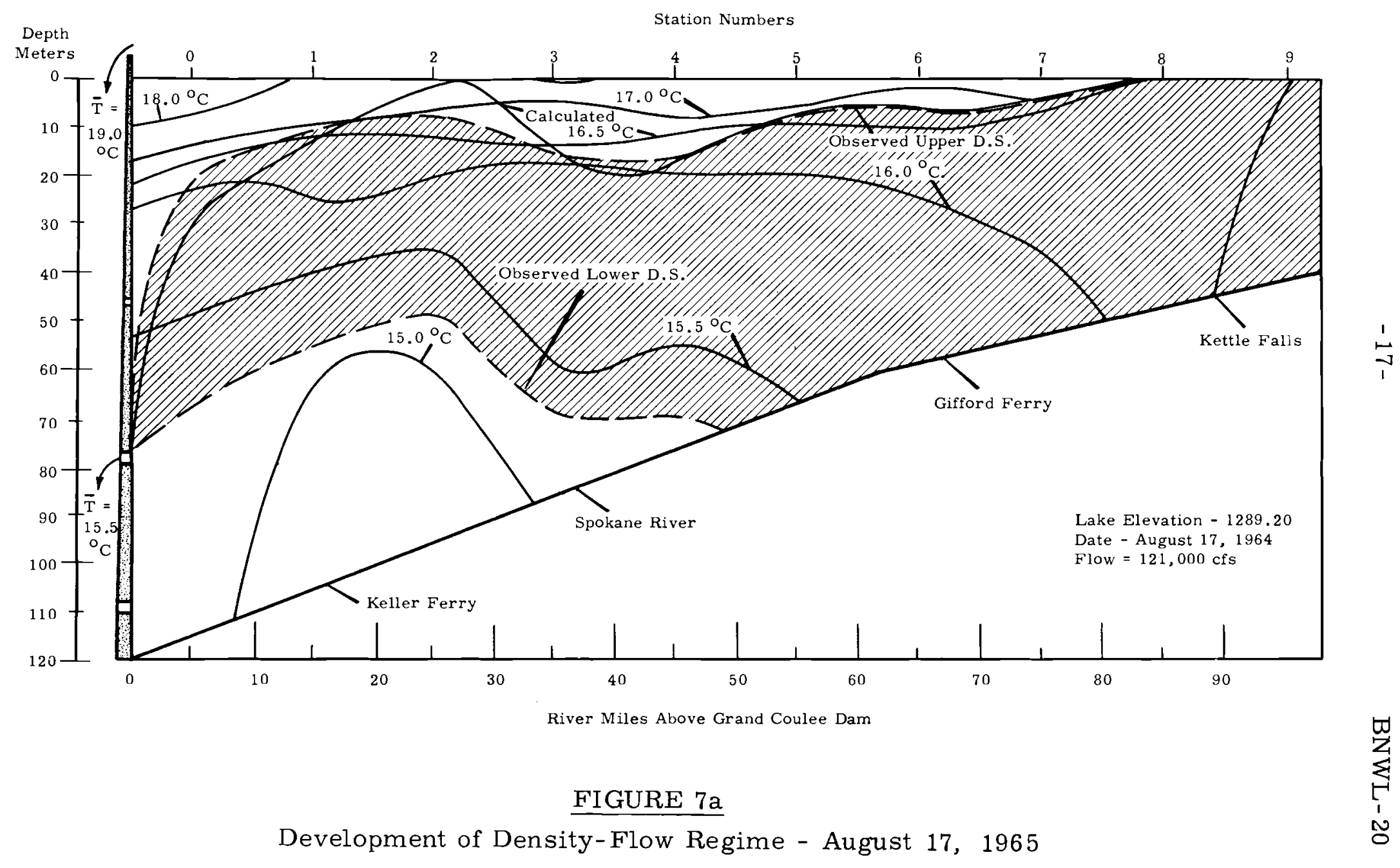




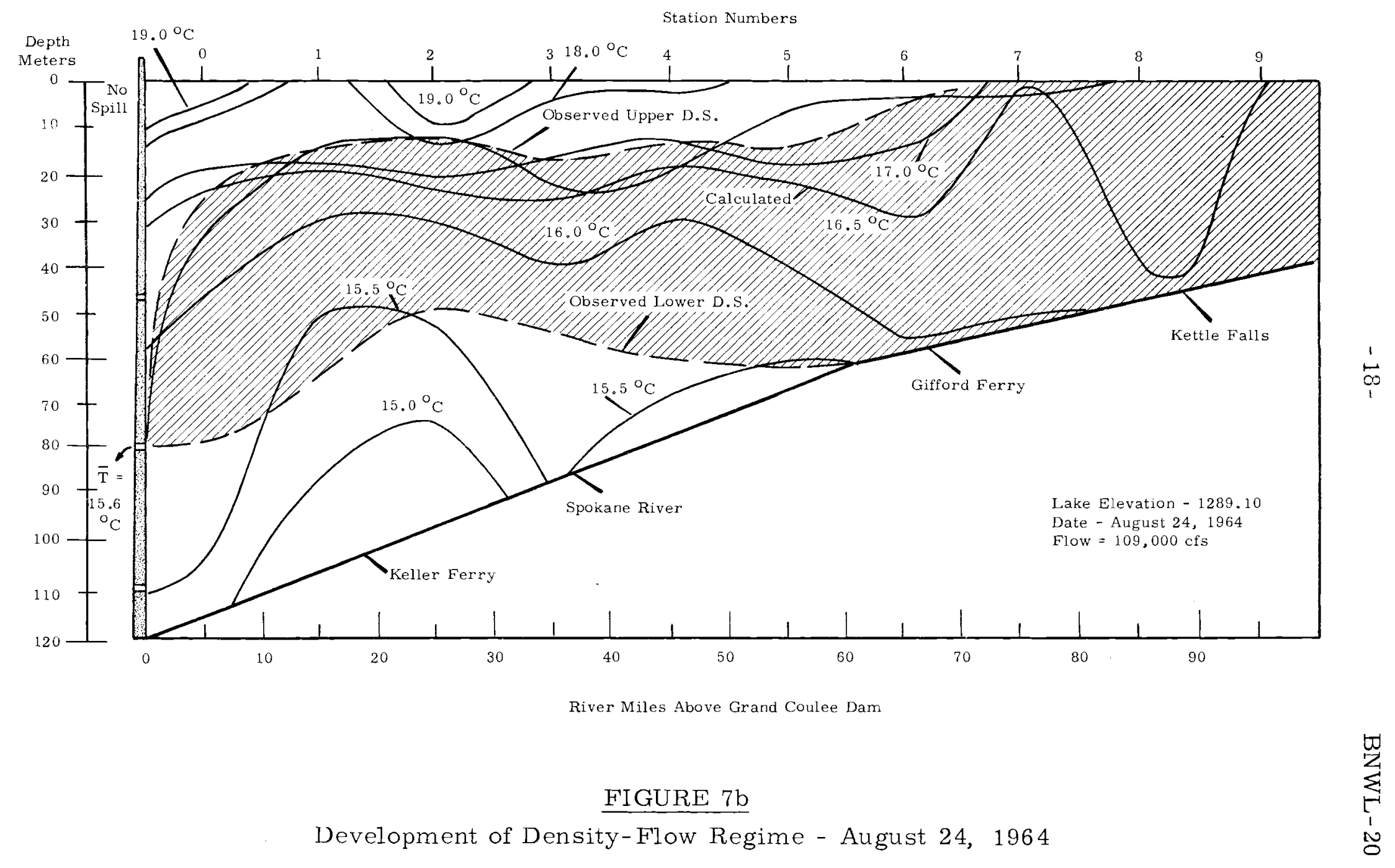




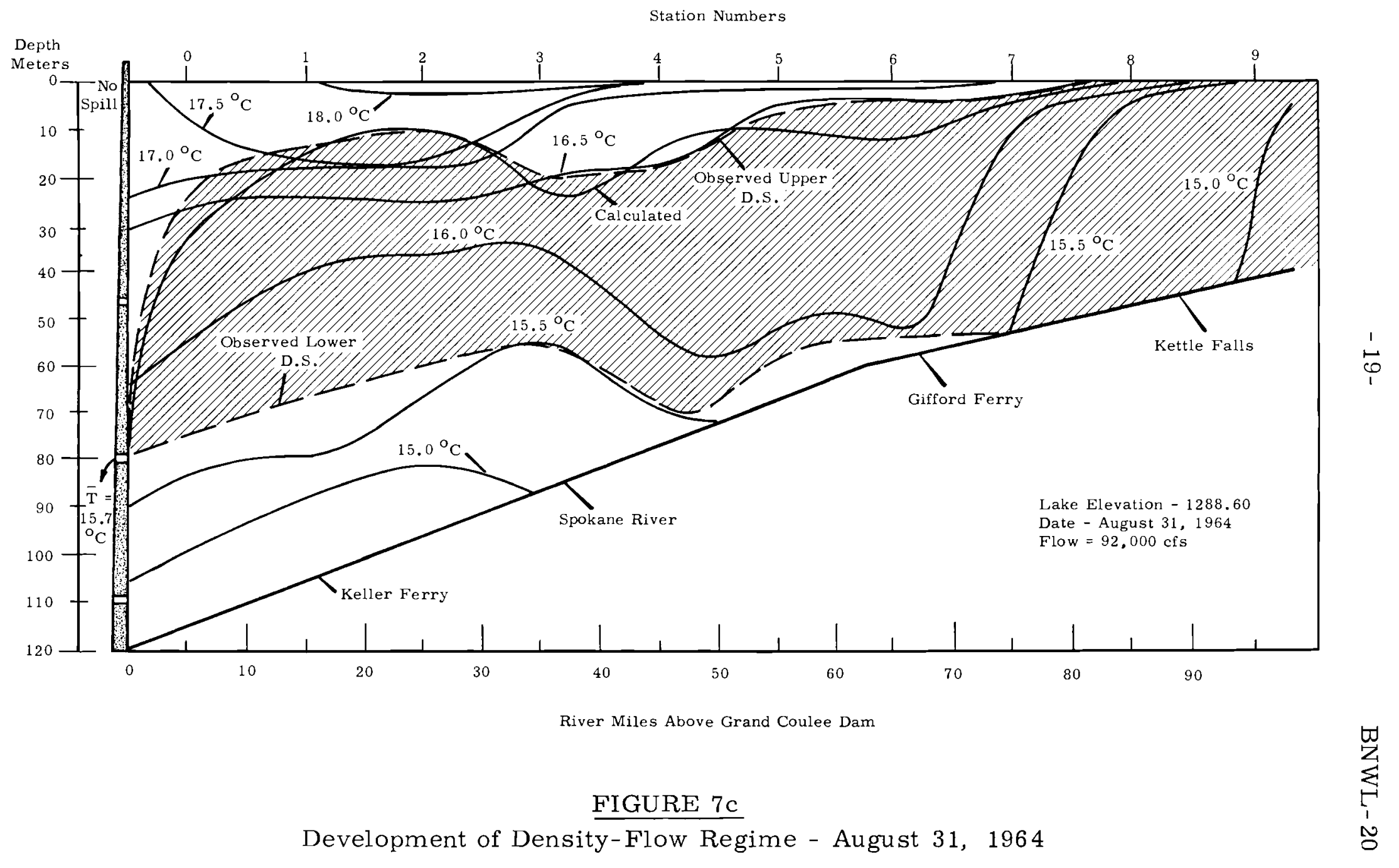




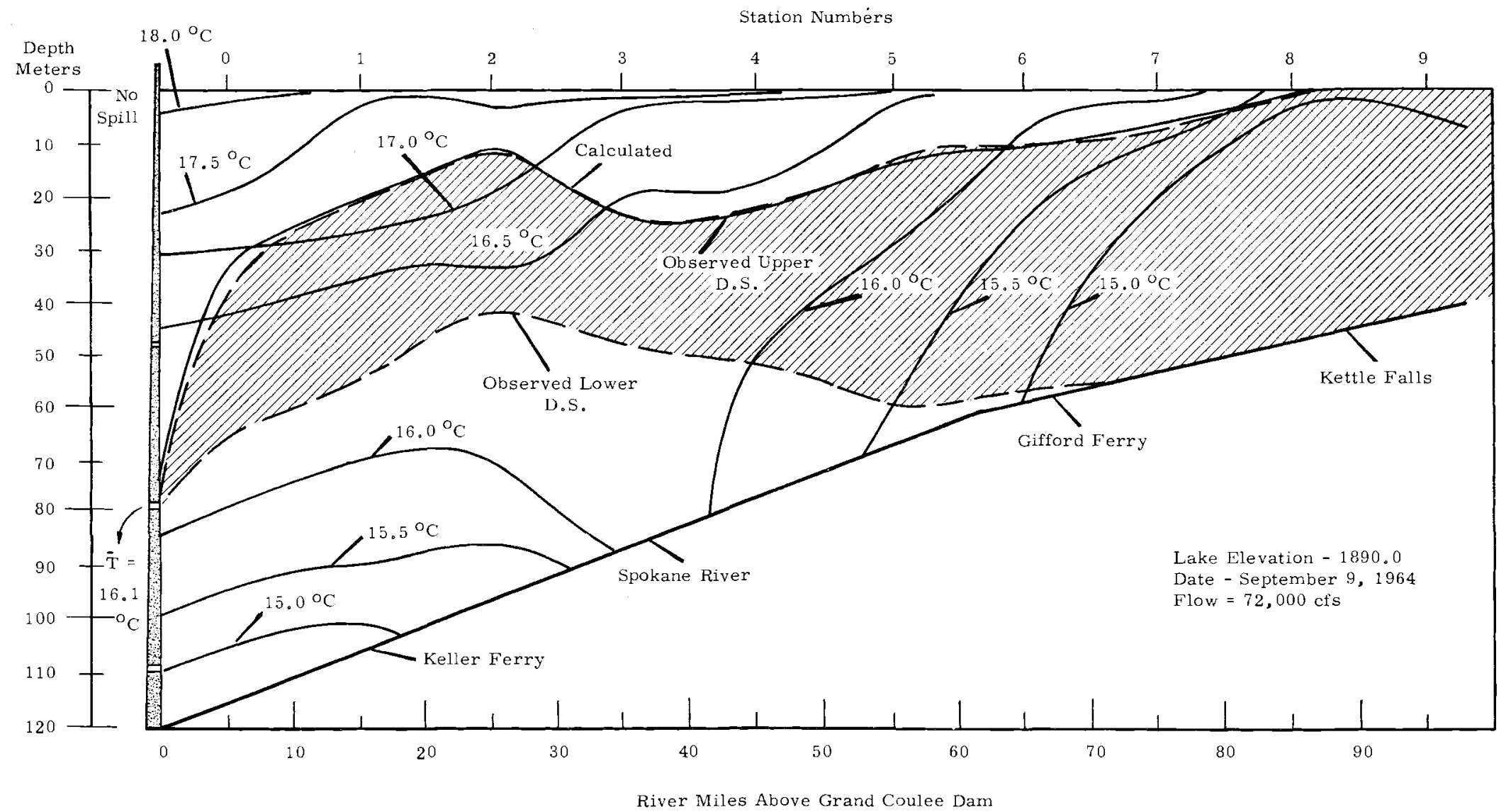

FIGURE 8a

Development of Density-Flow Regime - September 9, 1964 


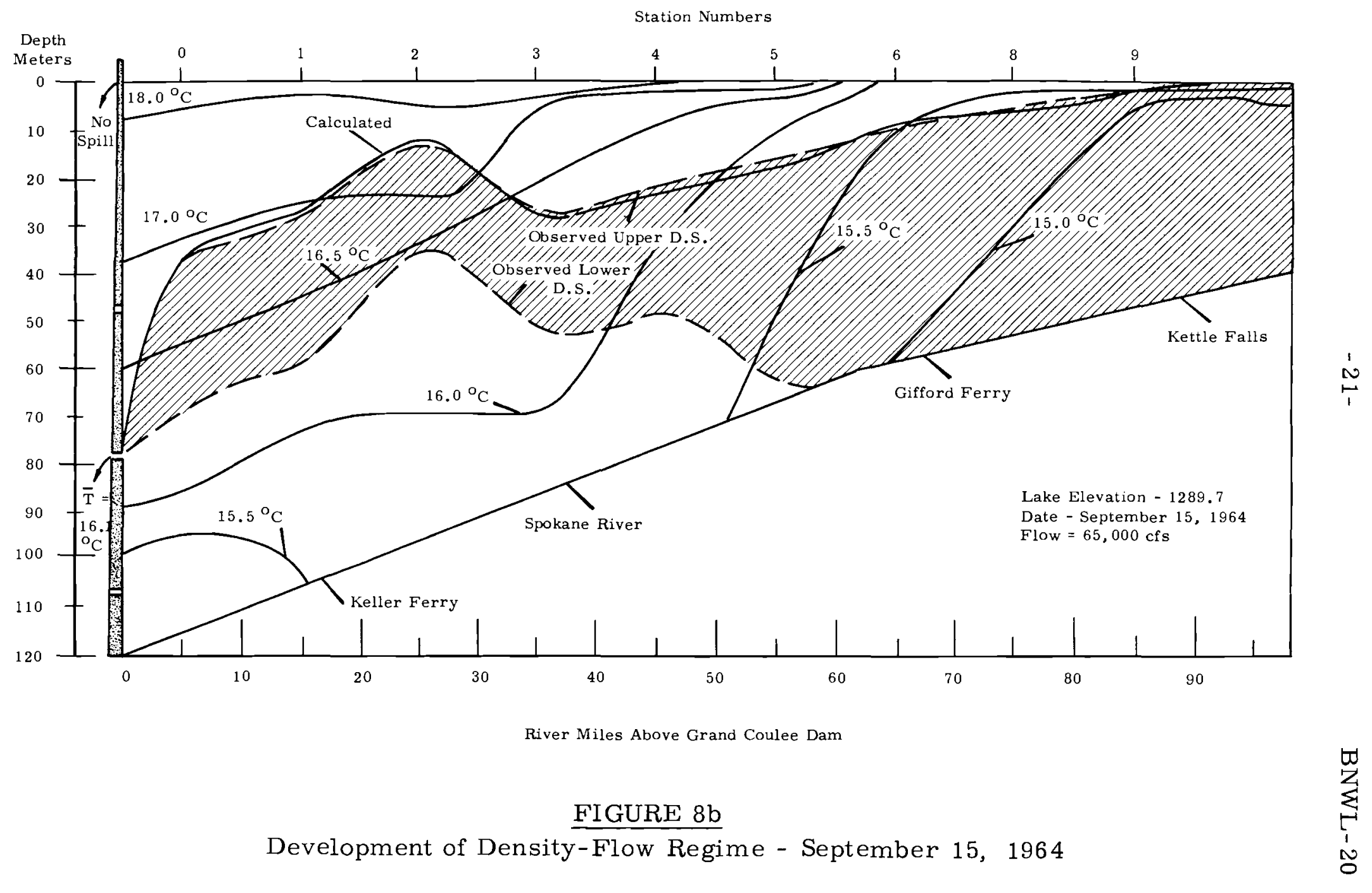




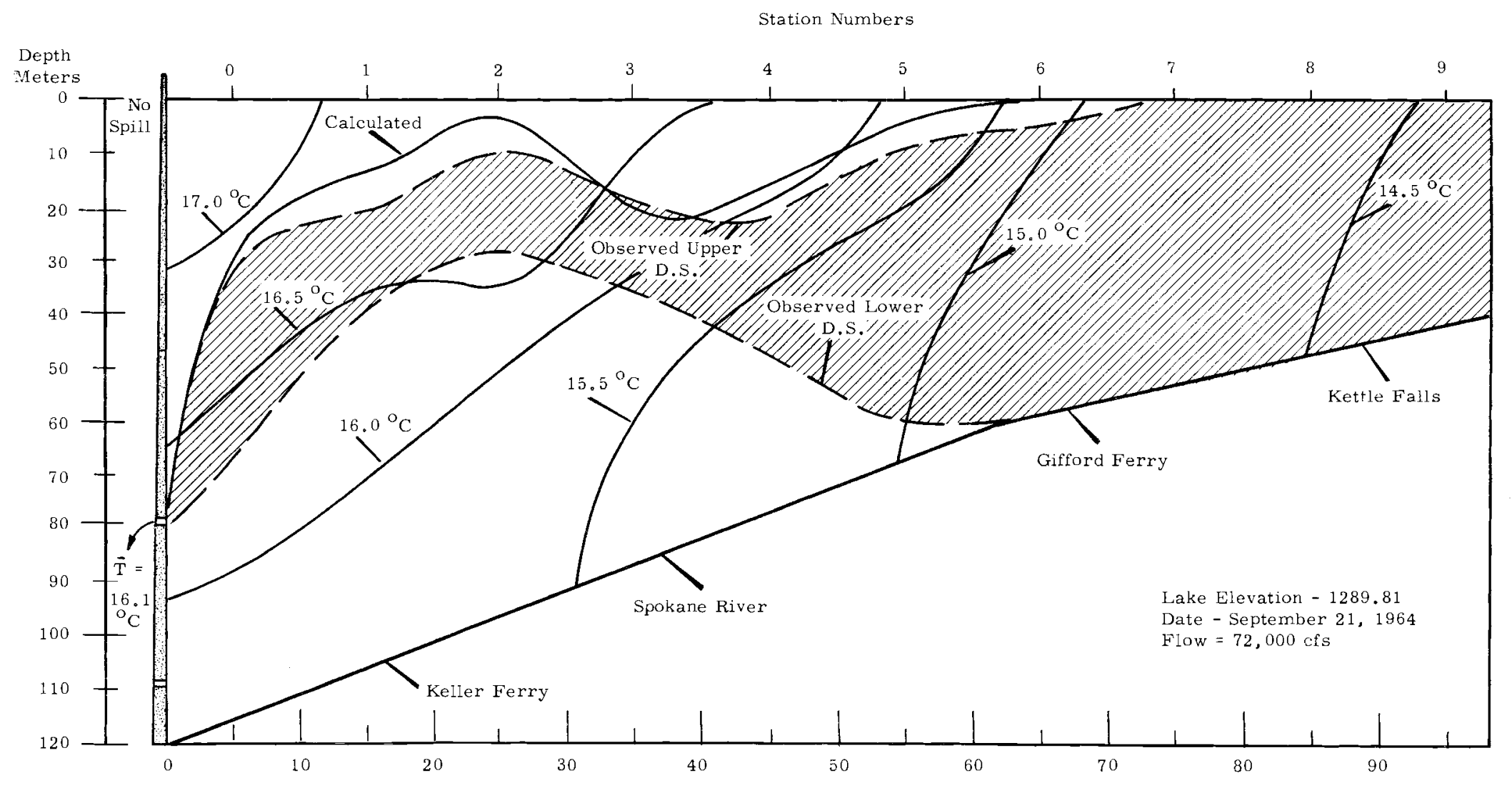

River Miles Above Grand Coulee Dam

FIGURE 8c

Development of Density-Flow Regime - September 21, 1964 


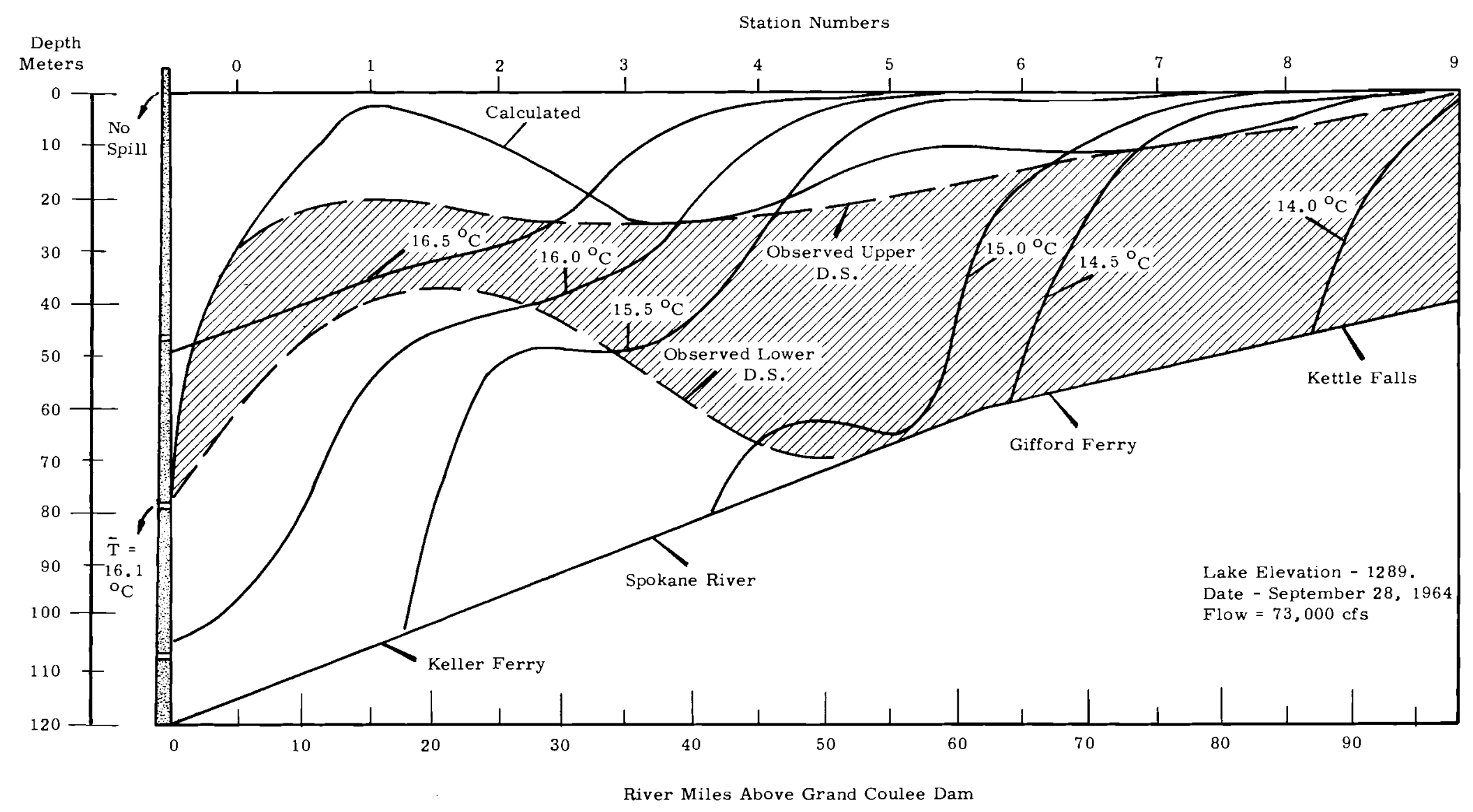

\section{FIGURE 9a}

Development of Density-Flow Regime - September 28, 1964 
Station Numbers

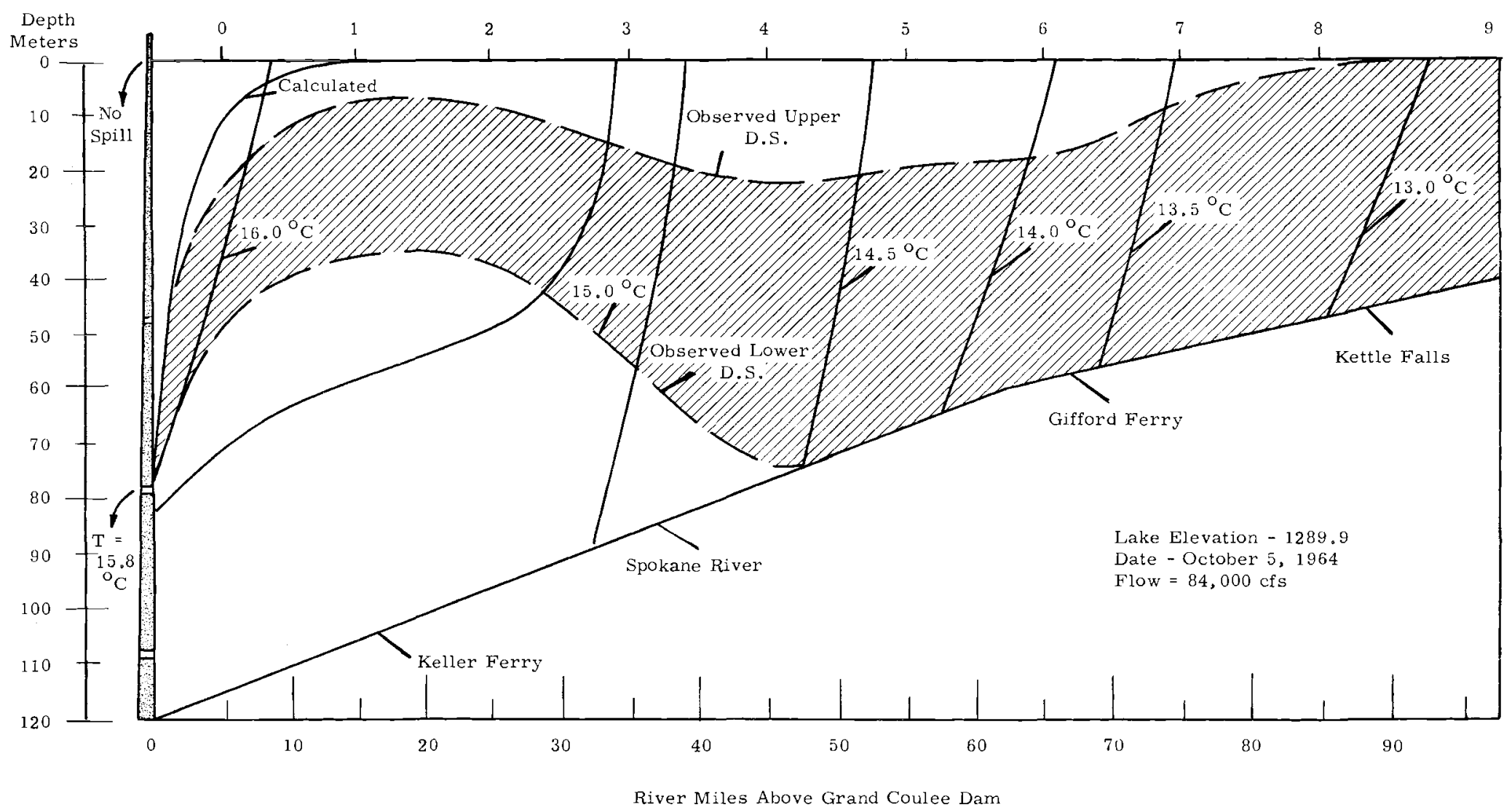

FIGURE 9b

Development of Density-Flow Regime - October 5, 1964 


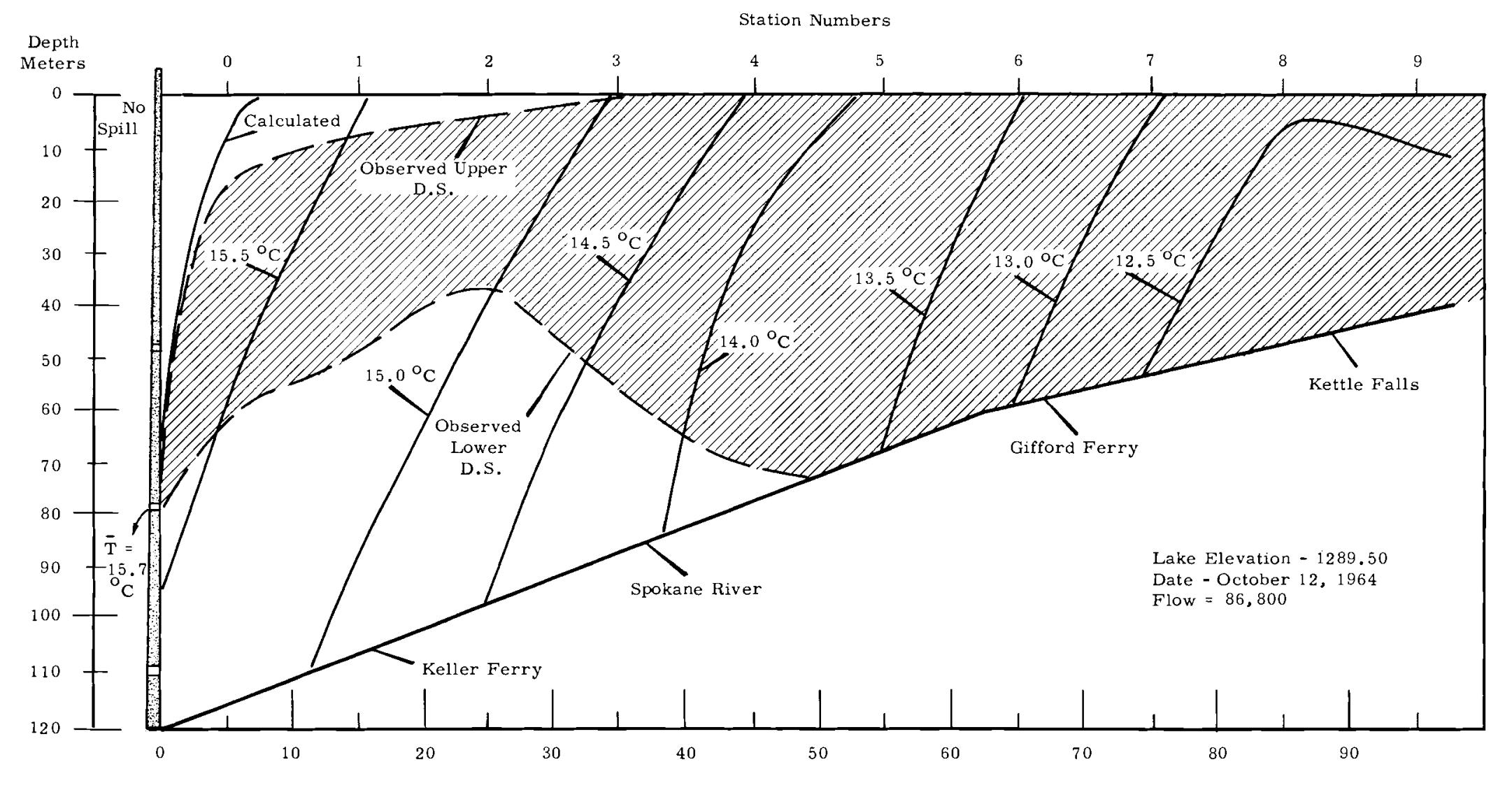

River Miles Above Grand Coulee Dam

FIGURE 9c

Development of Density-Flow Regime - October 12, 1964 


\section{REFERENCES}

1. M. A. Churchill. "Control of Temperature Through Streamflow Regulation, "Presented at U. S. PHS Symposium on Streamflow Regulation for Quality Control, April 3-5, 1963.

2. J. C. Ward. "Annual Variation of Stream Water Temperature, " J. Sanit. Eng. Div. - Am. Soc. Civil Eng. December 1963.

3. C. S. Yih. "On the Flow of a Stratified Fluid, "Proc. 3rd Nat, Congress of Appl. Mech. 1958.

4. W. R. Debler. "Stratified Flow into a Line Sink, "J. Eng. Mech. Div., Am. Soc. of Civil Eng. July, 1959.

5. N. Duncan, O. R. F. Harleman, R. A. Elder. "International Density Currents Created by Withdrawal from a Stratified Reservoir, " Published by Tenn. Val. Auth. and U. S. Corps of Engr, Norris Tenn. February 1962 .

\section{Additional Material of Interest}

E. O. Macagno. "Instability in the Zone of Establishment of a Density Stratified Flow, "Presented at VIII 'emes Journe'es de L'Hydraulique Lille, France. 1964. 
APPENDIX 1

ROOSEVELT LAKE TEMPERATURE (C) SURVEY

CONDUCTED ON SEPTEMBER 3, 1964

(United States Fish and Wildlife Service)

\begin{tabular}{|c|c|c|c|c|c|c|c|c|c|c|c|}
\hline \multirow{2}{*}{\multicolumn{2}{|c|}{ Depth - Meters }} & \multicolumn{10}{|c|}{ Station } \\
\hline & & 0 & 1 & 2 & 3 & 4 & 5 & 6 & 7 & 8 & 9 \\
\hline Surface & & 18. 1 & 18.1 & 18.0 & 17.6 & 17.9 & 16.8 & 16.7 & 16.2 & 14.8 & 14.5 \\
\hline 10 & 3.05 & 17.7 & 18.1 & 17.8 & 17.1 & 16.8 & 16.5 & 16.3 & 16.2 & 14.8 & 14.5 \\
\hline 20 & 6.1 & 17.6 & 17.6 & 17.5 & 16.8 & 16.6 & 16.3 & 16.2 & 16.1 & 14.8 & 14.5 \\
\hline 30 & 9.15 & 17.6 & 17.5 & 17.4 & 16.7 & 16.5 & 16. 2 & 16.2 & 16.0 & 14.8 & 14.5 \\
\hline 40 & 12.2 & 17.5 & 17.5 & 17.4 & 16.7 & 16.4 & 16. 2 & 16.2 & 15.7 & 14.8 & 14.5 \\
\hline 50 & 15.3 & 17.5 & 17.4 & 17.4 & 16.6 & 16. 4 & 16. 2 & 16.1 & 15.6 & 14.8 & 14.5 \\
\hline 60 & 18.3 & 17.5 & 17. 4 & 17.3 & 16.6 & 16. 4 & 16.2 & 16.1 & 15.5 & 14.8 & 14.5 \\
\hline 70 & 21.3 & 17.5 & 17.3 & 17.2 & 16.6 & 16.4 & 16.2 & 16.1 & 15.4 & 14.8 & 14.5 \\
\hline 80 & 24.4 & 16.9 & 17.0 & 16.8 & 16.5 & 16.3 & 16.2 & 16.1 & 15.4 & 14.8 & 14.5 \\
\hline 90 & 27.4 & 16.7 & 16.6 & 16.5 & 16.4 & 16.3 & 16.2 & 16.0 & 15.4 & 14.8 & \\
\hline 100 & 30.5 & 16.6 & 16.4 & 16.2 & 16.3 & 16.3 & 16. 2 & 16.0 & 15.4 & 14.8 & \\
\hline 110 & 33.5 & 16.5 & 16.3 & 16. 2 & 16.2 & 16. 3 & 16.2 & 16.0 & 15.3 & 14.8 & \\
\hline 120 & 36.6 & 16.4 & 16.3 & 16.1 & 16.2 & 16.3 & 16.2 & 15.8 & 15.2 & & \\
\hline 130 & 39.6 & 16.3 & 16.2 & 16.1 & 16.2 & 16.3 & 16.2 & 15.8 & 15.2 & & \\
\hline 140 & 42.6 & 16.2 & 16.2 & 16.0 & 16. 1 & 16.2 & 16.2 & 15.8 & 15.2 & & \\
\hline 150 & 45.7 & 16.2 & 16.2 & 16.0 & 16. 1 & 16.2 & 16.2 & 15.8 & 15.2 & & \\
\hline 160 & 48.8 & 16.2 & 16.1 & 15.9 & 16. 1 & 16. 1 & 16.2 & 15.8 & 15. 2 & & \\
\hline 170 & 51.8 & 16.2 & 16.0 & 15.8 & 16.0 & 16.0 & 16. 2 & 15.8 & 15.2 & & \\
\hline 180 & 54.8 & 16.1 & 16.0 & 15.8 & 16.0 & 16.0 & 16.1 & 15.8 & 15.2 & & \\
\hline 190 & 57.9 & 16.1 & 16.0 & 15.8 & 15.8 & 16.0 & 15.9 & 15.7 & 15.2 & & \\
\hline 200 & 61 & 16.0 & 15.9 & 15.7 & 15.7 & 16.0 & 15.7 & & & & \\
\hline 210 & 64 & 16.0 & 15.9 & 15.7 & 15.6 & 15.8 & 15.5 & & & & \\
\hline 220 & 67 & 15.9 & 15.8 & 15.6 & 15.5 & 15.7 & & & & & \\
\hline 230 & 70 & 15.8 & 15.8 & 15.6 & 15.4 & 15.6 & & & & & \\
\hline 240 & 73 & 15.8 & 15.8 & 15.5 & 15.4 & & & & & & \\
\hline 250 & 76 & 15.8 & 15.7 & 15.4 & 15.4 & & & & & & \\
\hline 260 & 79 & 15.7 & 15.6 & 15.2 & & & & & & & \\
\hline 270 & 84.3 & 15.6 & 15.5 & 15.1 & & & & & & & \\
\hline 280 & 85.3 & 15.6 & 15.4 & 15.0 & & & & & & & \\
\hline 290 & 88.4 & 15.4 & 15.2 & 14. 7 & & & & & & & \\
\hline 300 & 91.5 & 15.4 & 15.0 & 14.6 & & & & & & & \\
\hline 310 & 94.5 & 15.2 & 15.0 & 14.6 & & & & & & & \\
\hline 320 & 97.5 & 15.0 & 14.4 & 14.5 & & & & & & & \\
\hline 330 & 100.3 & 15.0 & 14.1 & & & & & & & & \\
\hline 340 & 103.6 & 15.0 & & & & & & & & & \\
\hline 350 & 106.8 & & $\begin{array}{l}\text { Bottom } \\
\text { Mud }\end{array}$ & & & & & & & & \\
\hline Time & & $\begin{array}{l}3: 15 \\
\text { p. m. }\end{array}$ & $\begin{array}{l}2: 40 \\
\text { p. m. }\end{array}$ & $\begin{array}{l}2: 00 \\
\text { p. m. }\end{array}$ & $\begin{array}{l}1: 25 \\
\text { p.m. }\end{array}$ & $\begin{array}{l}12: 45 \\
\text { p. m. }\end{array}$ & $\begin{array}{l}12: 10 \\
\text { a. } \mathrm{m} \text {. }\end{array}$ & $\begin{array}{l}11: 35 \\
\text { a. } \mathrm{m} \text {. }\end{array}$ & $\begin{array}{l}10: 35 \\
\text { a. } \mathrm{m} \text {. }\end{array}$ & $\begin{array}{l}10: 00 \\
\text { a. m. }\end{array}$ & $\begin{array}{l}8: 40 \\
\text { a. m. }\end{array}$ \\
\hline Station & $\begin{array}{l}\text { 0-Plum } \\
1 \text { - Keller } \\
2 \text { - White } \\
3 \text { - Spokar } \\
\text { 4- Log D }\end{array}$ & $\begin{array}{l}\text { Point } \\
\text { Ferry } \\
\text { Stone Ro } \\
\text { ne } \\
\text { ump }\end{array}$ & & Station & $\begin{array}{l}5-\mathrm{H} \\
6-\mathrm{G} \\
7-\mathrm{C} \\
3-\mathrm{C} \\
9-\mathrm{E}\end{array}$ & $\begin{array}{l}\text { inters } \\
\text { fford F } \\
\text { alk Cli } \\
\text { liville F } \\
\text { rans }\end{array}$ & $\begin{array}{l}\text { erry } \\
\text { ffs } \\
\text { River }\end{array}$ & & & & \\
\hline
\end{tabular}


APPENDIX 2

ROOSEVELT LAKE SURVEY CURRENT SPEED DATA

Šeptember 2, 3, 1964

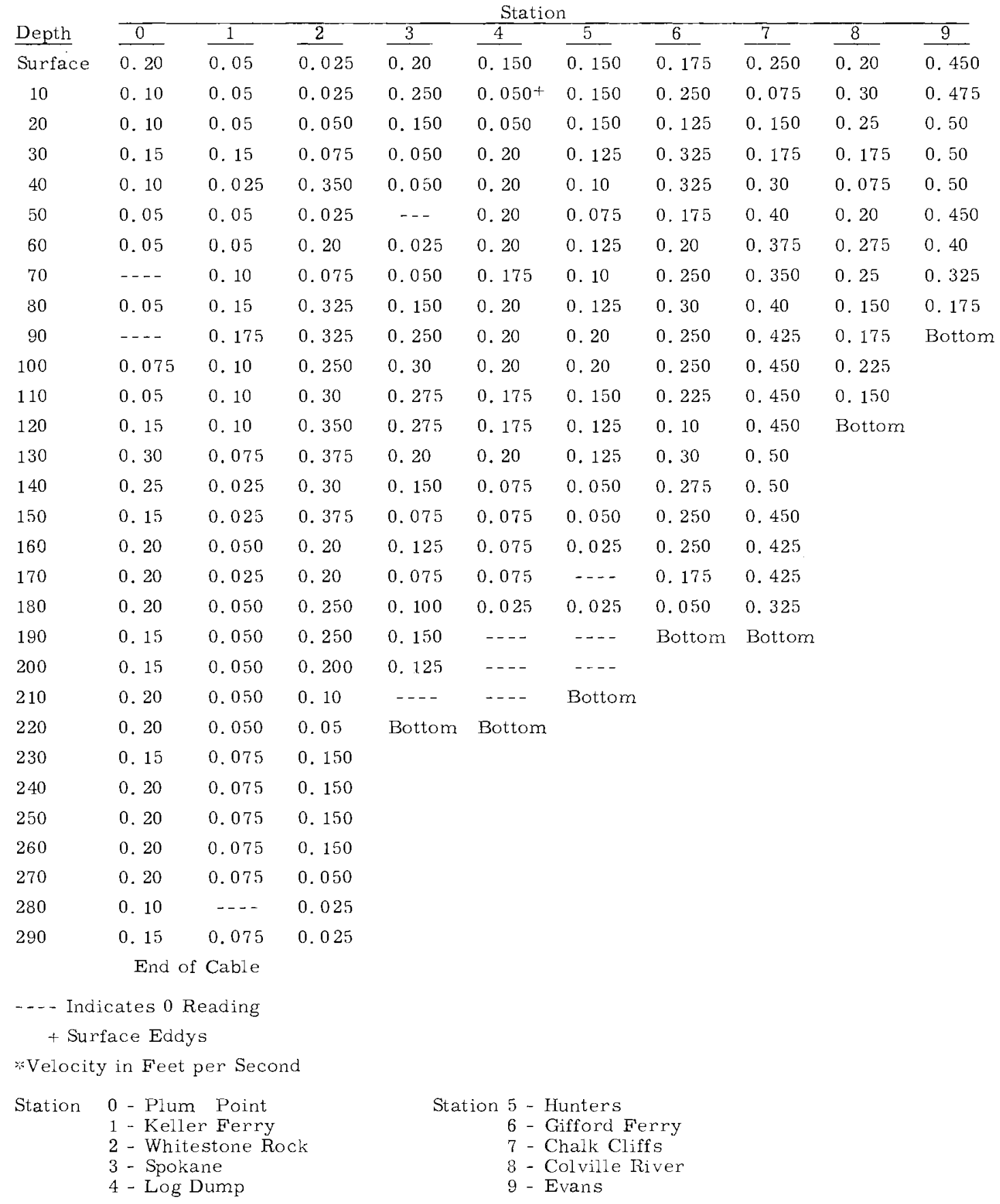




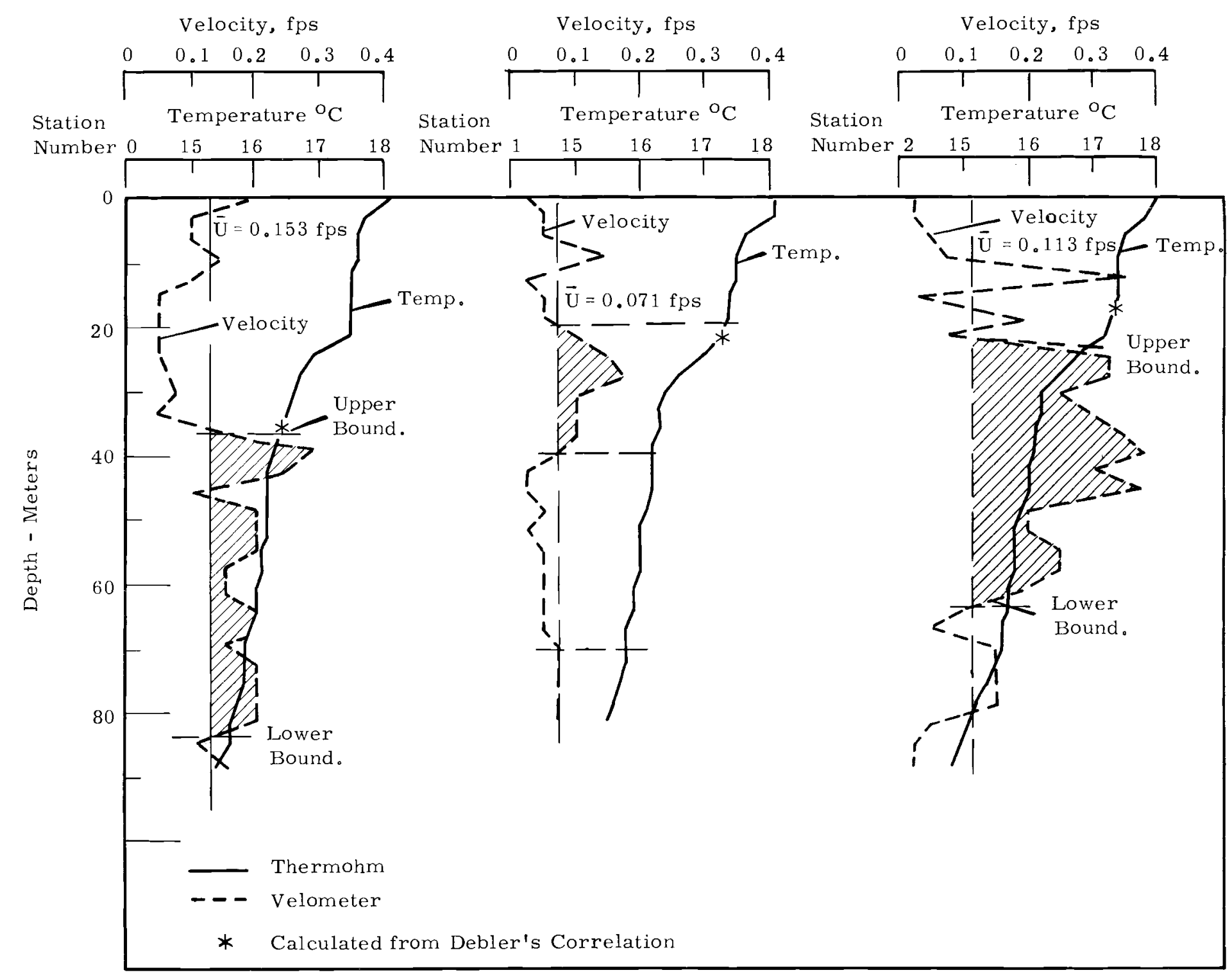




\section{APPENDIX 4}

DENSITY CURRENT BOUNDARY CALCULATION

(DATA: LAKE ROOSEVELT; SEPTEMBER 3, 1964)

(1) Evaluate: $F_{i}=\frac{Q}{W_{O} D_{0}^{2}} \sqrt{\frac{\rho_{0}}{g}}$

(2) Determine: $\mathrm{D}_{\mathrm{o}} / \mathrm{D}_{1}$

\section{ST ATION}

Width, ft at $\mathrm{D}_{\mathrm{O}}$

Flow, $\mathrm{ft}^{3} / \mathrm{sec}$

\begin{tabular}{lllllllll}
2100 & 1350 & 1000 & 1900 & 2000 & 1500 & 1800 & 2400 & 2100 \\
\\
\hline
\end{tabular}

Estimated Depth of Density Current, Average, ft.

$\begin{array}{lrrrrrrrr}260 & 250 & 240 & 230 & 220 & 210 & 200 & 160 & 130\end{array}$

$\mathrm{D}_{\mathrm{O}}^{2}$

$6.75 \times 10^{4} 6.25 \times 10^{4} \quad 5.75 \times 10^{4} \quad 5.3 \times 10^{4} \quad 4.8 \times 10^{4} \quad 4.4 \times 10^{4} \quad 4.0 \times 10^{4} \quad 2.56 \times 10^{4} \quad 1.64 \times 10^{4} \quad 0.81 \times 10^{4}$

Temperature at $D_{0}, C$

(1) $\frac{\mathrm{Q}}{\mathrm{W}_{\mathrm{O}} \mathrm{D}_{\mathrm{O}}^{2}}=$
15.8
15.7
15.5
15.4
$15.8 \quad 15.6$
15. 7
15.2
14. 8
14.5

$0.514 \times 10^{-3} 1.017 \times 10^{-3} 1.245 \times 10^{-3} 0.705 \times 10^{-3} 0.744 \times 10^{-3} 0.520 \times 10^{-3} 0.99 \times 10^{-3} 1.164 \times 10^{-3} 1.02 \times 10^{-3} 10.31 \times 10^{-3}$

Surface Temperature, T, C

$\begin{array}{llllllllll}18.1 & 18.1 & 18.0 & 17.6 & 17.9 & 16.8 & 16.7 & 16.2 & 14.8 & 14.5 \\ 62.370 & 62.371 & 62.373 & 62.375 & 62.370 & 62.374 & 62.372 & 67.377 & 62.381 & 62.384 \\ \underline{62.343} & \underline{62.343} & \underline{62.344} & \underline{62.349} & \underline{62.345} & \underline{62.359} & \underline{62.360} & \underline{62.366} & \underline{62.381} & \underline{62.384} \\ 0.027 & 0.028 & 0.029 & 0.026 & 0.025 & 0.015 & 0.012 & 0.011 & 0 & 0\end{array}$

Density at $D_{0} l b / \mathrm{ft}^{3}$

Density at $\mathrm{D}_{1} \mathrm{lb} / \mathrm{ft}^{3}$

$\Delta \partial$

$R=\frac{\Delta \partial}{\mathrm{ft}}, \mathrm{lb} / \mathrm{ft}^{4}$

(2) $\frac{\rho_{0}}{g}$

(1) $(2)=F_{i}$

$\mathrm{D}_{\mathrm{O}} / \mathrm{D}_{1}$ From Debler

Depth Fraction

Depth, Meters

$10.4 \times 10^{-5} 11.2 \times 10^{-5} 12.1 \times 10^{-5} 11.3 \times 10^{-5} 11.3 \times 10^{-5} 7.15 \times 10^{-5} 6 \times 10^{-5} 6.9 \times 10^{-5} 00$

$\begin{array}{llllllllll}136 & 131 & 126 & 131 & 131 & 161 & 180 & 167 & - & - \\ 0.070 & 0.132 & 0.156 & 0.090 & 0.046 & 0.092 & 0.178 & 0.196 & >\frac{1}{\pi} & >\frac{1}{\pi} \\ 0.53 & 0.71 & 0.77 & 0.60 & 0.61 & 0.60 & 0.83 & 0.86 & 1.0 & 1.0 \\ 0.47 & 0.29 & 0.23 & 0.40 & 0.39 & 0.40 & 0.17 & 0.14 & 0 & 0 \\ 36 & 22 & 17 & 28 & 26 & 26 & 10.5 & 9 & 0 & 0\end{array}$




\section{INTERNAL DISTRIBUTION}

Copy Number

$\begin{array}{ll}1 & \text { E. R. Astley } \\ 2 & \text { J. P. Corley } \\ 3 & \text { R. F. Foster } \\ 4 & \text { J. B. Goebel } \\ 5 & \text { R. B. Hall } \\ 6 & \text { H. E. Hanthorn } \\ 7 & \text { F. P. Hungate } \\ 8 & \text { E. R. Irish } \\ 9-28 & \text { R. T. Jaske } \\ 29 & \text { R. L. Junkins } \\ 30 & \text { R. E. Nakatani } \\ 31 & \text { J. L. Nelson } \\ 32 & \text { J. M. Nielson } \\ 33 & \text { H. M. Parker } \\ 34 & \text { W. D. Richmond } \\ 35 & \text { W. B. Silker } \\ 36 & \text { C. J. Touhill } \\ 37 & \text { E. E. Voiland } \\ 38 & \text { F. W. Woodfield } \\ 39 & \text { Technical Publications } \\ 40-44 & \text { Technical Information Files }\end{array}$

EXTERNAL DISTRIBUTION (SPECIAL)

Number of Copies

General Electric Company

Attn: L. B. Brinkman

R. G. Geier

H. W. Heacock

R. T. Jessen

R. A. R. Kent

R. L. Reynolds

RLOO

Attn: A. T. Gifford

H. E. Parker

R. K. Sharp

Technical Information Iibrary

R. D. Wildman 
UC-2

GENERAL, MISCELLLANEOUS, AND PROGRESS REPORTS

Ptd.
Standard Distribution

ABERDEEN PROVING GROUND

AEROJET-GENERAL CORPORATION

AEROJET-GENERAL NUCLEONICS

AR FORCE INSTITUTE OF TECHNOLOGY

AIR FORCE INSTITUTE OF TECHNOLOGY (MAFB)

ALLIS-CHALMERS MANUFACTURING COMPANY

ALLIS-CHALMERS MANUFACTURING COMPANY, BETHESDA

ARGONNE CANCER RESEARCH HOSPITAL

ARGONNE NATIONAL LABORATORY

ARMED FORCES RADIOBIOLOGY RESEARCH INSTITUTE

ARMY CHEMICAL RESEARCH AND DEVELOPMENT LABORATORIES

ARMY ELECTRONICS RESEARCH AND DEVELOPMENT LABORATORIES

ARMY MAT ERIALS RESEARCH AGENCY

ARMY NUCLEAR DEFENSE LABORATORY

ATOMIC BOMB CASUALTY COMMISSION

ATOMIC ENERGY COMMSSION, BETHESDA

AEC SCIENTIFIC REPRESENTATIVE, BELGIUM

AEC SCIENTIFIC REPRESENTATIVE, FRANCE

AEC SCIENTIFIC REPRESENTATIVE, JAPAN

ATOMIC ENERGY COMMISSION, WASHINGTON

ATOMIC ENERGY OF CANADA LIMITED

ATOMIC ENERGY OF CANADA LIMITED, TORONTO

ATOMIC ENERGY OF CANADA LIMITED, WHITESHELL

ATOMICS INTERNATIONAL

AYCO CORPORATION

BABCOCK AND WILCOX COMPANY

BATTELLE MEMORIAL INSTITUTE

^BATTELLE.NORTHWEST

BERYLLIUM CORPORATION

BROOKE ARMY MEDICAL CENTER

BROOKHAVEN NATIONAL LABORATORY

BUREAU OF MINES, ALBANY

BUREAU OF SHIPS (CODE 1500)

CARNEGIE INSTITUTE OF TECHNOLOGY

39 th Ed.

TID-4500

Ptd.

1

1

1

I

3

1
Standard Distribution

CHICAGO PATENT GROUP

COMBUSTION ENGINEERING, INC.

COMBUSTION ENGINEERING, INC. (NRD)

COMMITTEE ON THE EFFECTS OF ATOMIC RADIATION

DEFENCE RESEARCH MEMBER

DEL ELECTRONICS CORPORATION

DENYER RESEARCH INSTITUTE

DOW CHEMICAL COMPANY, ROCKY FLATS

DU PONT COMPANY, AIKEN

DU PONT COMPANY, WILMINGTON

EDGERTON, GERMESHAUSEN AND GRIER, INC., GOLETA

FRANKFORD ARSENAL

FUNDAMENTAL METHODS ASSOCIATION

GENERAL ATOMIC DIVISION

GENERAL DYNAMICS/FORT WORTH

general electric COMPANy, CINCINHATI

GENERAL ELECTRIC COMPANY (MSYD)

GENERAL ELECTRIC COMPANY, SAN JOSE

GOODYEAR ATOMIC CORPORATION

hAZLETON NUCLEAR SCIENCE CORPORATION

HUGHES AIRCRAFT COMPANY

IIT RESEARCH INSTITUTE

*INTER-AMERICAN INSTITUTE OF AGRICULTURAL SCIENCES

IOWA STATE UNIVERSITY

JET PROPULSION LABORATORY

KNOLLS ATOMIC POWER LABORATORY

LING TEMCO VOUGHT, INC.

LOS ALAMOS SCIENTIFIC LABORATORY

LOWRY AIR FORCE BASE

MALLINCKRODT CHEMICAL WORKS

MARTIN-MARIET TA CORPORATION

MOUND LABORATORY

NASA LANGLEY RESEARCH CENTER

NASA LEWIS RESEARCH CENTER

NASA LE WIS RESEARCH CENTER, SANDUSKY

NASA NANNED SPACECRAFT CENTER 


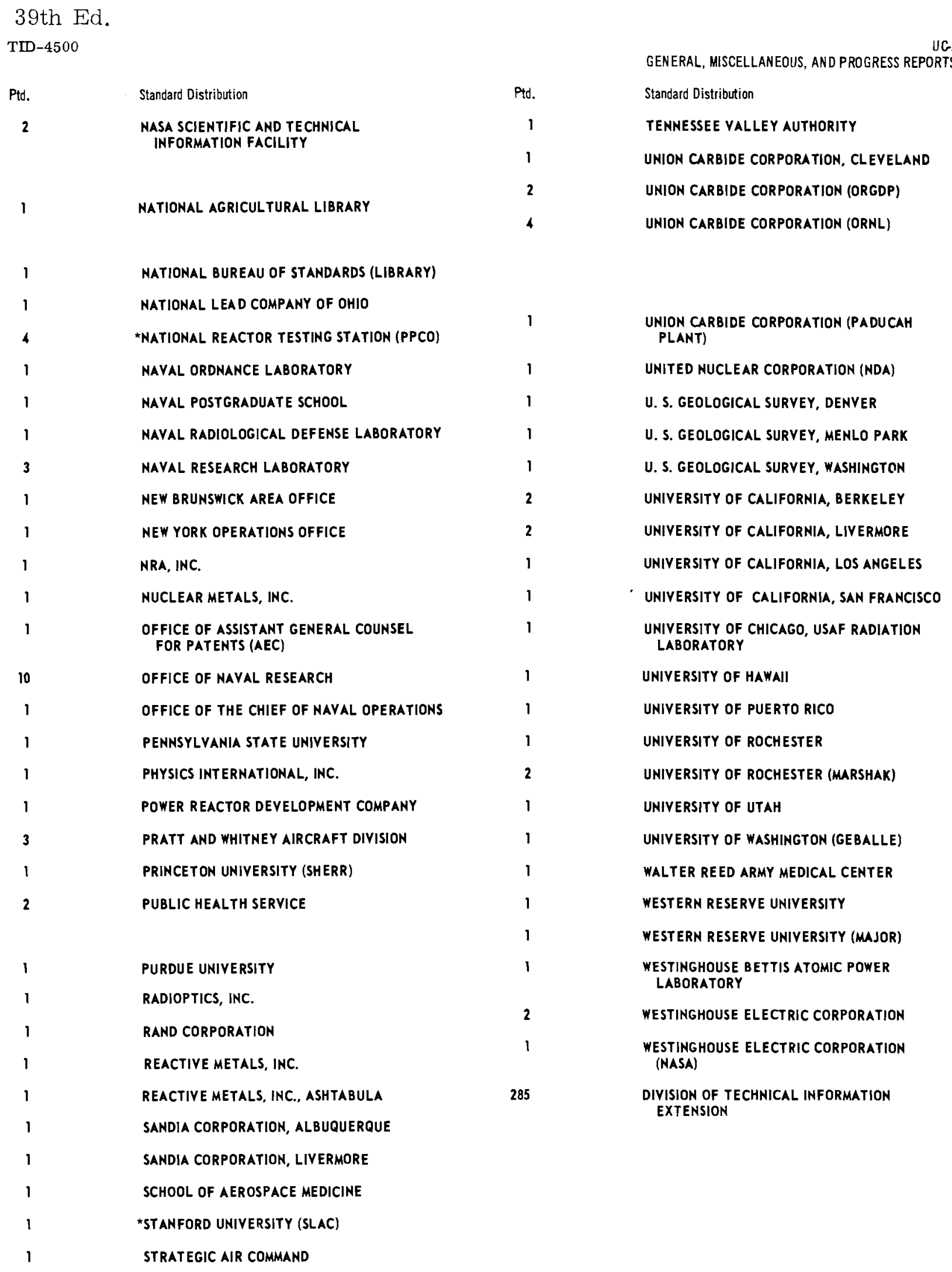


2

,

$+$ 